\title{
A synthesis of light absorption properties of the Arctic Ocean: application to semianalytical estimates of dissolved organic carbon concentrations from space
}

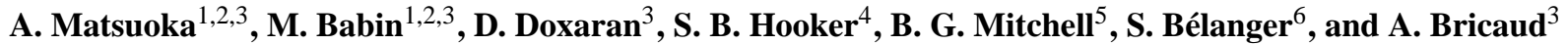 \\ ${ }^{1}$ Takuvik Joint International Laboratory, Département de Biologie, Université Laval, 1045, avenue de la Médecine, Québec, \\ QC, G1V 0A6, Canada \\ ${ }^{2}$ Takuvik Joint International Laboratory, CNRS, 1045, avenue de la Médecine, Québec, QC, G1V 0A6, Canada \\ ${ }^{3}$ Laboratoire d'Océanographie de Villefranche, Université Pierre et Marie Curie(Paris 6)/CNRS, B.P. 8, Villefranche-sur-Mer \\ Cedex, 06238, France \\ ${ }^{4}$ National Aeronautics and Space Administration (NASA)/ Goddard Space Flight Center (GSFC), Code 616.2, Bldg. 28 Rm. \\ W120D, Greenbelt, MD 20771, USA \\ ${ }^{5}$ Scripps Institution of Oceanography, University of California San Diego, La Jolla, CA 92093-0238, USA \\ ${ }^{6}$ Université du Québec à Rimouski, Département de Biologie, Chimie et Géographie, 300 allée des Ursulines, Rimouski, \\ Québec, G5L 3A1, Canada
}

Correspondence to: A. Matsuoka (atsushi.matsuoka@takuvik.ulaval.ca)

Received: 21 September 2013 - Published in Biogeosciences Discuss.: 1 November 2013

Revised: 11 April 2014 - Accepted: 14 April 2014 - Published: 16 June 2014

\begin{abstract}
In addition to scattering coefficients, the light absorption coefficients of particulate and dissolved materials are the main factors determining the light propagation of the visible part of the spectrum and are, thus, important for developing ocean color algorithms. While these absorption properties have recently been documented by a few studies for the Arctic Ocean (e.g., Matsuoka et al., 2007, 2011; Ben Mustapha et al., 2012), the data sets used in the literature were sparse and individually insufficient to draw a general view of the basin-wide spatial and temporal variations in absorption. To achieve such a task, we built a large absorption database of the Arctic Ocean by pooling the majority of published data sets and merging new data sets. Our results show that the total nonwater absorption coefficients measured in the eastern Arctic Ocean (EAO; Siberian side) are significantly higher than in the western Arctic Ocean (WAO; North American side). This higher absorption is explained by higher concentration of colored dissolved organic matter (CDOM) in watersheds on the Siberian side, which contains a large amount of dissolved organic carbon (DOC) compared to waters off North America. In contrast, the relationship between the phytoplankton absorption $\left(a_{\varphi}(\lambda)\right)$ and chlorophyll
\end{abstract}

$a$ (chl $a$ ) concentration in the EAO was not significantly different from that in the WAO. Because our semianalytical CDOM absorption algorithm is based on chl $a$-specific $a_{\varphi}(\lambda)$ values (Matsuoka et al., 2013), this result indirectly suggests that CDOM absorption can be appropriately derived not only for the WAO but also for the EAO using ocean color data. Based on statistics, derived CDOM absorption values were reasonable compared to in situ measurements. By combining this algorithm with empirical DOC versus CDOM relationships, a semianalytical algorithm for estimating DOC concentrations for river-influenced coastal waters of the Arctic Ocean is presented and applied to satellite ocean color data.

\section{Introduction}

The Arctic Ocean faces dramatic changes in physical environments driven by ongoing global warming. Decreases in both sea ice extent and thickness (Comiso et al., 2008; Kwok, 2007; Stroeve et al., 2008) facilitate the propagation of light into the water column, creating favorable conditions for phytoplankton's photosynthetic processes when 
nutrients are available in the upper layer of the water column (e.g., Ardyna et al., 2013). Recent papers showed that an increase in primary production (PP) is significantly and positively correlated with open water area (Arrigo and van Dijken, 2011), suggesting that autochthonous dissolved organic carbon (DOC) resulting from the increased PP could be a nonnegligible source for open waters (Wheeler et al., 1996). More importantly, in terms of the DOC budget, DOC concentrations in river-influenced coastal waters are much higher than for open waters (Benner et al., 2005; Stedmon et al., 2011; Amon et al., 2012, Matsuoka et al., 2012). In addition to autotrophic sources, it is expected that recent increases in river discharges modify (Stedmon et al., 2011) (1) the total amount of DOC discharged to the Arctic Ocean; (2) the seasonality of the riverine export by increasing the flux of DOC during the base-flow period (November-May), when material is older, more bio-refractory and could be transported far in the Arctic Ocean under the ice cover in winter; and (3) the relative contributions of the large Arctic rivers (e.g., Lena vs. Yenisei) with consequences on DOC distribution in the Arctic Ocean. However, a comprehensive method for quantifying and continuously monitoring DOC concentrations, which takes into account their temporal and geographical variability for river-influenced coastal waters of the Arctic Ocean, is presently not available.

One of the best approaches to achieve this task is to apply a semianalytical algorithm to satellite ocean color data. Such an algorithm was recently developed for the southern Beaufort Sea (Mackenzie Shelf area) waters in the Canadian Arctic (Matsuoka et al., 2013). The accuracy in the estimates of DOC concentrations using this approach relies upon an accurate retrieval of absorption coefficients of colored dissolved organic matter, CDOM, at $443 \mathrm{~nm}\left(a_{\mathrm{CDOM}}(443)\right.$, $\mathrm{m}^{-1}$ ), and on the robustness of the relationship between DOC and $a_{\mathrm{CDOM}}(443)$. The CDOM algorithm of Matsuoka et al. (2013) is based on a parameterization of absorption properties. To determine whether this algorithm can be applied to regions of the Arctic Ocean other than the Mackenzie Shelf area, the geographical variability of those optical properties must be determined.

The main objective of the present study is therefore to examine absorption properties for various waters of the Arctic Ocean. Based on these results, a semianalytical algorithm for estimating DOC concentrations in river-influenced coastal waters of the Arctic Ocean is presented and applied to satellite ocean color data.

\section{Data sets and methods}

\subsection{In situ measurements}

To provide a general overview of absorption properties, we built a large absorption database of the Arctic Ocean by pooling the majority of published data (Fig. 1; Table 1). Although

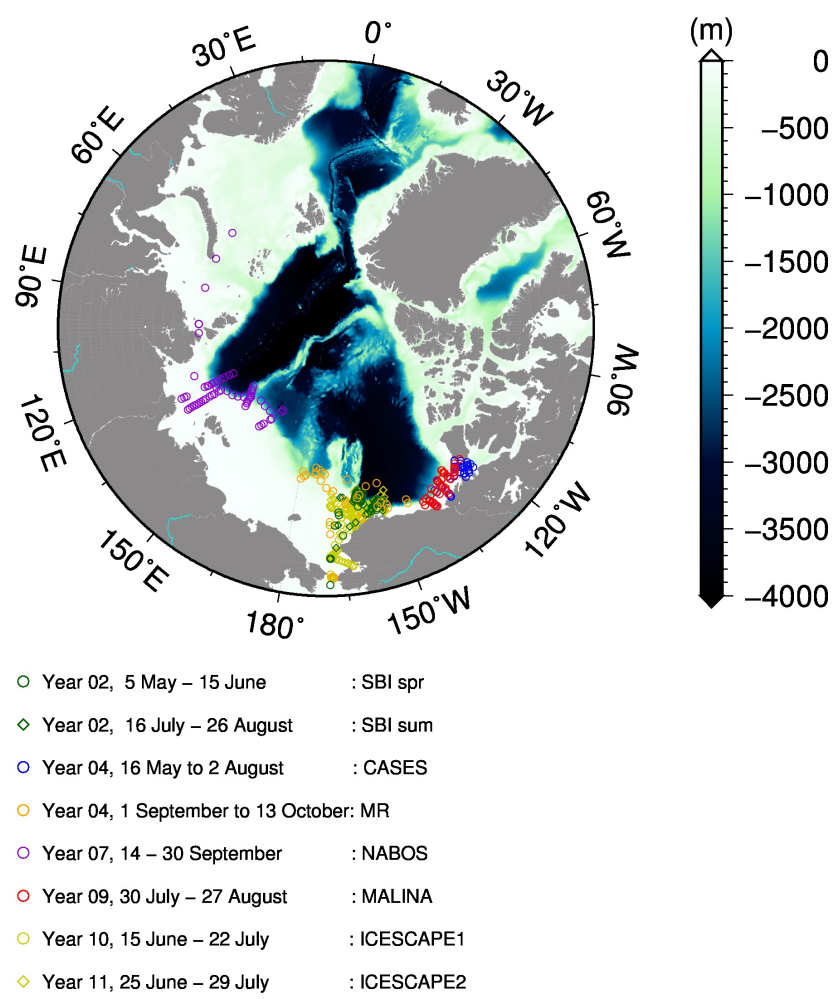

Figure 1. Locations of sampling stations for the SBI spr (green circles), SBI sum (green diamonds), CASES (blue circles), MR aut (orange circles), NABOS (purple circles), MALINA (red circles), ICESCAPE1 (gold circles), and ICESCAPE2 (gold diamonds) in the Arctic Ocean.

data from the Canadian Archipelago, the Greenland and Barents seas were not included, our data set is quality checked and the largest for the Arctic Ocean. Additional data will be included to cover wider areas in the future.

In the western Arctic Ocean (WAO), data were collected during the following five cruises from spring to autumn: the Western Arctic Shelf Basin Interaction, SBI, (1) spring and (2) summer cruises aboard the USCGS Healy (referred to as SBI spr: 5 May-15 June 2002, and SBI sum: 16 July26 August 2002, respectively), (3) the Japanese Arctic cruise aboard R/V Mirai (referred to as MR: 1 September-13 October 2004), (4) the Canadian Arctic Shelf Exchange Study (CASES) cruise aboard CCGS Amundsen (referred to as CASES: 16 May-2 August 2004), and (5) the MALINA cruise aboard CCGS Amundsen (referred to as MALINA: 30 July-27 August 2009). In the eastern Arctic Ocean (EAO), data were collected during the NABOS (Nansen and Amundsen Basins Observational System) cruise aboard R/V Viktor Buynitsky (referred to as NABOS: 14 September-30 September 2007). To minimize geographic bias due to a large number of data in the Chukchi Sea and western part of the southern Beaufort Sea, absorption data sets from ICESCAPE2010 and ICECAPE2011 cruises (referred to as ICESCAPE1: 15 June-22 July 2010, and ICESCAPE2: 25 June-29 July, 2011, 
Table 1. Summary of our absorption data sets. The total nonwater absorption $\left(a_{\mathrm{tw}}(\lambda), \mathrm{m}^{-1}\right)$, and individual contribution by phytoplankton $\left(a_{\phi}(\lambda), \mathrm{m}^{-1}\right)$, NAP $\left(a_{\mathrm{NAP}}(\lambda), \mathrm{m}^{-1}\right)$, and $\operatorname{CDOM}\left(a_{\mathrm{CDOM}}(\lambda), \mathrm{m}^{-1}\right)$ are shown. To obtain $a_{\phi}(\lambda)$ and $a_{\mathrm{NAP}}(\lambda)$ values, a different $\beta$ factor was used for each instrument because of the different geometry and phytoplankton species composition (see below; $N$ indicates the number of samples).

\begin{tabular}{lllcccccc}
\hline Year & Season & Cruise & $a_{\mathrm{tw}}(443)$ & $\% a_{\phi}(443)$ & $\% a_{\mathrm{NAP}}(443)$ & $\% a_{\mathrm{CDOM}}(443)$ & $N$ & $\beta$ factor \\
\hline 2002 & Spring & SBI spr & $0.10 \pm 0.04$ & $27 \pm 0.15$ & $15 \pm 10$ & $58 \pm 20$ & 68 & 1 \\
2002 & Summer & SBI sum & $0.11 \pm 0.13$ & $31 \pm 0.14$ & $16 \pm 10$ & $53 \pm 16$ & 107 & 1 \\
$2003-$ & Spring/Summer & CASES & $0.19 \pm 0.20$ & $16 \pm 0.15$ & $15 \pm 10$ & $68 \pm 18$ & 112 & $2^{\mathrm{a}}$ \\
2004 & /Autumn & & & & & & & \\
2004 & Autumn & MR & $0.10 \pm 0.06$ & $18 \pm 12$ & $8 \pm 5$ & $74 \pm 14$ & 179 & 1 \\
2007 & Summer & NABOS & $0.32 \pm 0.15$ & $8 \pm 4$ & $8 \pm 4$ & $85 \pm 7$ & 18 & $3^{\mathrm{a}}$ \\
2009 & Summer & MALINA & $0.19 \pm 0.45$ & $13 \pm 9$ & $15 \pm 15$ & $73 \pm 18$ & 119 & $4^{\mathrm{b}}$ \\
\hline Average & All & All & $0.14 \pm 0.23$ & $20 \pm 14$ & $0.13 \pm 11$ & $68 \pm 19$ & 603 & - \\
\hline
\end{tabular}

1: Cleveland and Weidemann (1993)

2: Tassan and Ferrari. (1995, 2002)

3: Bricaud and Stramski. (1990); Allali et al. (1997)

4: Rottgers and Gehnke. (2012)

${ }^{a}$ Different $\beta$ factor was used for CASES (Tassan and Ferrari, 2002) and NABOS (Bricaud and Stramski, 1990; Allali et al., 1997) using the same PerkinElmer 19 spectrophotometer equipped with a $60 \mathrm{~mm}$ integrating sphere. During the NABOS cruise (autumn), a mean value of chl $b$ to chl $a$ ratio of 0.15 was observed, which was similar to that obtained in the southern Beaufort Sea over the same time period (0.19) when a mixture of small phytoplankton (e.g., flagellates) dominated (Matsuoka et al., 2009). This result suggests that small phytoplankton dominated in EAO waters during the NABOS cruise. Bricaud and Stramski. (1990) and Allali et al. (1997) obtained a $\beta$ factor for a smaller type of phytoplankton species, which was applied for the NABOS data set. For the CASES cruise, large phytoplankton such as diatoms dominated (Terrado et al., 2008). Tassan and Ferrari. (1995, 2002) determined a $\beta$ factor for larger phytoplankton, which was applied to the CASES data set.

b A PerkinElmer 19 spectrophotometer equipped with a $150 \mathrm{~mm}$ integrating sphere was used.

respectively) were not used for our main results. Instead, these independent data sets were used for evaluating the Bricaud and Stramski (1990) method to derive phytoplankton absorption (see Appendix A2). Radiometric data obtained from MALINA, ICESCAPE1, and ICESCAPE2 were used for evaluating a semianalytical CDOM algorithm developed by Matsuoka et al. (2013) (based on a method explained in Sect. 2.1.3).

Discrete water samples were collected using Niskin bottles, except at the surface where a clean container was used during the MR cruise. During the six cruises, 30, 29, 51, 94, 37, and 57 stations (SBI spr, SBI sum, MR, CASES, MALINA, and NABOS, respectively) were visited to collect water samples for pigment and absorption analyses within the euphotic zone (i.e., between the surface and the euphotic depth, $\mathrm{z}_{\mathrm{eu}}$, defined as the depth of penetration of $1 \%$ of the surface photosynthetically available radiation (PAR)). Absorption coefficients of particles $\left(\mathrm{a}_{p}(\lambda), \mathrm{m}^{-1}\right)$ retained on GF/F (glass fiber) filters were determined from 350 to $750 \mathrm{~nm}$ using a MPS-2400 spectrophotometer (Shimazu Corp.) for SBI spr, SBI sum, and MR, and a Lambda 19 spectrophotometer (PerkinElmer) for CASES, NABOS, and MALINA. Because two spectrophotometers with different geometries were used for absorption measurements, the corresponding and appropriate pathlength amplification effect caused by the highly scattering GF/F filter, known as the $\beta$ factor (Mitchell and Kiefer, 1988), was taken into account for each instrument (see Table 1 for details).

Phytoplankton pigments retained on the filters were extracted using methanol (Kishino et al., 1985). Absorption co- efficients of nonalgal particles, NAP $\left(a_{\mathrm{NAP}}(\lambda), \mathrm{m}^{-1}\right)$, were determined on the depigmented filter. Phytoplankton absorption coefficients $\left(a_{\varphi}(\lambda), \mathrm{m}^{-1}\right)$ were finally obtained by subtracting $a_{\mathrm{NAP}}(\lambda)$ from $\mathrm{a}_{p}(\lambda)$. For the NABOS cruise, only $\mathrm{a}_{p}(\lambda)$ data were available. To obtain $a_{\varphi}(\lambda)$ and $a_{\mathrm{NAP}}(\lambda)$, a numerical decomposition method proposed by Bricaud and Stramski (1990) was applied to this data set. An evaluation of this method for Arctic samples is presented in Appendix A2. All absorption measurements were made following the NASA Ocean Optics Protocols (Mitchell et al., 2003) except the MALINA data, for which we followed Rottgers and Gehnke (2012). Spectral slopes of NAP, $\mathrm{S}_{\mathrm{NAP}}\left(\mathrm{nm}^{-1}\right)$ were calculated by fitting a nonlinear model to the data from 380 to $730 \mathrm{~nm}$, excluding the $400-480$ and $620-710 \mathrm{~nm}$ ranges to avoid any residual pigment absorption (Babin et al., 2003).

For the CDOM absorption measurements, water samples were filtered using $0.2 \mu \mathrm{m}$ pore-size filters immediately after sampling (see details for sample preparation in Mitchell et al., 2003 and Matsuoka et al., 2012). Absorption coefficients of CDOM $\left(a_{\mathrm{CDOM}}(\lambda), \mathrm{m}^{-1}\right)$ were determined from 280 to $700 \mathrm{~nm}$ using a MPS2400 spectrophotometer (Shimazu corp.) for SBI spr, SBI sum, and MR. For the CASES cruise, the filtrates were frozen at $-20^{\circ} \mathrm{C}$ and shipped to the laboratory at Rimouski. $a_{\mathrm{CDOM}}(\lambda)$ spectra were then measured using a Lambda 35 (PerkinElmer) from 250 to $800 \mathrm{~nm}$. Both spectrophotometers were equipped with $10 \mathrm{~cm}$ quartz cells (Bélanger et al., 2006; Matsuoka et al., 2011). For the MALINA cruise, an UltraPath liquid waveguide system was used (World Precision Instruments, Inc.), and $a_{\mathrm{CDOM}}(\lambda)$ was obtained from 200 to $735 \mathrm{~nm}$ (Matsuoka et al, 2012). For the 
NABOS cruise, $a_{\mathrm{CDOM}}(\lambda)$ was obtained at $412,443,488$, $510,532,555,630,676$, and $715 \mathrm{~nm}$ using an ac-9 (WET Labs) with $0.2 \mu \mathrm{m}$ inlet filter (Pegau et al., 2003). Spectral slopes of $\mathrm{CDOM}$ absorption $\left(\mathrm{S}_{\mathrm{CDOM}}, \mathrm{nm}^{-1}\right.$ ) were calculated by fitting a nonlinear model to the data from 350 to $500 \mathrm{~nm}$, except for the NABOS cruise, for which $\mathrm{S}_{\mathrm{CDOM}}$ was calculated using $a_{\mathrm{CDOM}}(\lambda)$ at $412,440,488$, and $510 \mathrm{~nm}$. The total nonwater absorption coefficient, $a_{t w}(\lambda)$ was calculated as the sum of $a_{\varphi}(\lambda), a_{\mathrm{NAP}}(\lambda)$, and $a_{\mathrm{CDOM}}(\lambda)$.

Chl $a$ concentrations were determined using either fluorometric methods (chl $a^{\text {fluo }}$ : Holm-Hansen et al., 1965; Suzuki and Ishimaru, 1990), high performance liquid chromatography (HPLC) (chl $a^{\text {HPLC }}$ : Ras et al., 2008), or both. A comparison between chl $a^{\text {fluo }}$ and chl $a^{\text {HPLC }}$ showed reasonable agreement $\left(r^{2}=0.89\right.$, intercept $=0.11$, slope $=0.98$, $N=177$; see Appendix A1). In this study, chl $a^{\mathrm{HPLC}}$ was used if available. Otherwise, $\operatorname{chl} a^{\text {fluo }}$ was used.

The detailed method for measuring concentrations of suspended particulate matter (SPM) is documented in Doxaran et al. (2012). Briefly, 0.2-6 L of seawater was filtered on a precombusted and preweighted GF/F filter. After filtration of seawater, filters were systematically rinsed with $0.2-0.6 \mathrm{~L}$ of Milli-Q water to remove sea salt. The reason for rinsing using Milli-Q water instead of ammonium formate solution proposed by ICES (2004) is that the latter product may leave carbon deposits on the filters. This would have contaminated the CHN analyses, also made on the SPM filters to determine their particulate carbon content (see Doxaran et al., 2012). The concentration of SPM was then calculated as the difference in weight before and after filtration divided by the volume of the sample $\left(\mathrm{g} \mathrm{m}^{-3}\right)$. The SPM concentrations were measured for the CASES, NABOS, and MALINA cruises.

\subsubsection{Calculation of remote sensing reflectance}

In-water upwelled radiance $\left(L_{\mathrm{u}}, \mu \mathrm{W} \mathrm{cm} \mathrm{cm}^{-2} \mathrm{~nm}^{-1} \mathrm{sr}^{-1}\right)$ and downward irradiance $\left(E_{\mathrm{d}}, \mu \mathrm{W} \mathrm{cm} \mathrm{cm}^{-2} \mathrm{~nm}^{-1}\right)$ were obtained at 19 wavelengths spanning from 320 to $780 \mathrm{~nm}$ following the NASA Ocean Optics Protocols (Mueller and Austin, 1995) and Hooker et al. (2013). Briefly, a compact-optical profiling system (C-OPS, Biospherical Instruments Inc.) (Morrow et al. 2010) was deployed at 36 and 19 stations for MALINA and ICESCAPE1 cruises, respectively. For the ICESCAPE2 cruise, a profiling reflectance radiometer series 800 (PRR800 , Biospherical Instruments Inc.) was deployed at 24 stations. In the present study, the independent data sets from these three cruises were used to evaluate a semianalytical algorithm for deriving CDOM absorption developed by Matsuoka et al. (2013). The above-water global solar irradiance $\left(E_{\mathrm{S}}\right)$ measurements were used to correct the $E_{\mathrm{d}}$ and $L_{\mathrm{u}}$ data for change in the incident light field during water column profiling. The in-water measurements were made far away from the main ship to minimize platform perturbations, and the above-water solar irradiance measurements were made to avoid superstructure shadows and reflections. The tilt an- gles were always less than $5^{\circ}$, as recommended by the NASA Ocean Optics Protocols (Mueller and Austin, 1995). Subsurface $L_{\mathrm{u}}$ at null depth (i.e., $L_{\mathrm{u}}\left(0^{-}, \lambda\right)$ ) was obtained from the slope and intercept given by the least-squares linear regression of the log-transformed upwelled radiance versus $z$. The principal data product used here is the remote sensing reflectance, $R_{\mathrm{rs}}(\lambda)=0.54 L_{\mathrm{u}}\left(0^{-}, \lambda\right) / E_{\mathrm{S}}(\lambda)$, where $\lambda$ indicates wavelength. In this study, $R_{\mathrm{rs}}(\lambda)$ at six wavelengths (i.e, $412,443,490,532,555$, and $670 \mathrm{~nm}$ corresponding approximately to MODerate-Resolution Imaging Spectroradiometer, MODIS, ocean color bands) were used to derive $a_{\mathrm{CDOM}}(\lambda)$ at $443 \mathrm{~nm}$ values based on a method explained in Sect. 2.1.3 (Matsuoka et al., 2013).

\subsubsection{Ocean color data}

Level 3 monthly averaged climatology data over the 20022012 period for $R_{\mathrm{rs}}(\lambda)$ at $412,443,488,531,555$, and $670 \mathrm{~nm}$, obtained from the MODIS Aqua ocean color sensor (http://oceandata.sci.gsfc.nasa.gov/MODISA/Binned/ Monthly_Climatology/), were used in this study. A semianalytical algorithm for deriving $a_{\mathrm{CDOM}}(443)$ based on the method detailed in Sect. 2.1.3 (Matsuoka et al., 2013) was then applied to the $R_{\mathrm{rs}}(\lambda)$ data. DOC concentration in riverinfluenced coastal waters were estimated using the relationships between DOC and $a_{\mathrm{CDOM}}(443)$ as shown in Sect. 2.1.3.

Level 2 daily $R_{\mathrm{rs}}(\lambda)$ at 412, 443, 488, 531, 555, and $670 \mathrm{~nm}$, obtained from the MODIS Aqua ocean color sensor (http://oceancolor.gsfc.nasa.gov/cgi/browse.pl?sen=am), were used to generate daily DOC concentrations images and examine its spatial and temporal variability (see Fig. 13).

\subsubsection{Semianalytical algorithms for deriving CDOM absorption and DOC concentration}

A detailed description of our semianalytical CDOM absorption algorithm is given in Matsuoka et al. (2013). Briefly, this algorithm produces $a_{\mathrm{CDOM}}(443)$ using $R_{\mathrm{rs}}(\lambda)$ at six wavelengths in the visible spectral domain corresponding to ocean color sensors (e.g., MODIS and MEdium Resolution Imaging Spectrometer, MERIS) by minimizing the difference between measured $R_{\mathrm{rs}}(\lambda)$ and $R_{\mathrm{rs}}(\lambda)$ calculated using absorption and backscattering coefficients, as in the Garver-SiegelMaritorena (GSM) algorithm (Garver and Siegel, 1997; Maritorena et a., 2002). The following modifications were included: (1) chl $a$ specific absorption coefficients of phytoplankton for Arctic waters (Matsuoka et al., 2011) were used; (2) spectral slopes of CDM absorption, $S_{\mathrm{CDM}}\left(\mathrm{nm}^{-1}\right)$ and of backscattering of particles $\left(b_{\mathrm{bp}}(\lambda), \mathrm{m}^{-1}\right), \eta$ (dimensionless) were set either to be constants or as functions of $R_{\mathrm{rs}}(\lambda)$ (those parameters were determined based on a sensitivity analysis following Matsuoka et al. (2013); (3) $b_{\mathrm{bp}}(555)$ was calculated using $b_{\mathrm{bp}}(443)$ and $\eta$; (4) $a_{\mathrm{NAP}}(443)$ was calculated using the empirical relationship between $a_{\mathrm{NAP}}(443)$ and $b_{b p}(555)$ obtained for Arctic waters (i.e., 
$a_{\mathrm{NAP}}(443)=b_{\mathrm{bp}}(555) / 0.2393$; Matsuoka et al., 2007); and (5) $a_{\mathrm{CDOM}}(443)$ was obtained by subtracting $a_{\mathrm{NAP}}(443)$ from $a_{\mathrm{CDOM}}(443)$. To estimate DOC concentrations in the nearsurface and river-influenced coastal waters using ocean color data, a relationship between DOC and $a_{\mathrm{CDOM}}(\lambda)$ needs to be established. Walker et al. (2013) recently showed a consistent relationship between DOC and CDOM absorption coefficient at $350 \mathrm{~nm}\left(a_{\mathrm{CDOM}}(350), \mathrm{m}^{-1}\right)$ for waters at the mouth of the five major Arctic rivers (i.e., Lena, Yenisei, $\mathrm{Ob}$, Mackenzie and Kolyma rivers; DOC $\left(\mathrm{mg} \mathrm{L}^{-1}\right)=2.907$ $\left.+0.4059 \cdot a_{\mathrm{CDOM}}(350)\right)$. The DOC vs. $a_{\mathrm{CDOM}}(350)$ relationship was converted into a DOC vs. $a_{\mathrm{CDOM}}(443)$ relationship by assuming a $\mathrm{S}_{\mathrm{CDOM}}$ of $0.0175 \mathrm{~nm}^{-1}$ calculated using data from 350 to $600 \mathrm{~nm}$ in the EAO, as reported by Aas et al. (2002) (i.e., DOC $(\mu \mathrm{M})=245+171 \cdot a_{\mathrm{CDOM}}(443)$ ). Stedmon et al.(2011) reported a lower $\mathrm{S}_{\mathrm{CDOM}}\left(0.0167 \mathrm{~nm}^{-1}\right)$ using the data from 300 to $650 \mathrm{~nm}$. While the use of a different data range for calculating a spectral slope makes it difficult to compare results (Twardowski et al., 2004), the spectral slope reported by Stedmon et al. (2011) would not be significantly different from the one by Aas et al. (2002) if the same data range is used: In any case, the choice of a spectral slope resulted in a change of only $7 \%$ for the slope of the DOC versus $a_{\mathrm{CDOM}}(443)$ relationship, which did not influence our results.

In the relationship converted in this study ( $D O C=245$ $\left.+171 \cdot a_{\mathrm{CDOM}}(443)\right)$, the intercept is too high for the mouth of the Mackenzie River $(245 \mu \mathrm{M})$ in the WAO, when compared to published values (55-97 $\mu \mathrm{M}$; Osburn et al., 2009; Matsuoka et al., 2012). The high intercept may be influenced by a lower DOC to $a_{\mathrm{CDOM}}(443)$ ratio at high $a_{\mathrm{CDOM}}(443)$ values $\left(>1.1 \mathrm{~m}^{-1}\right)$ in the EAO (see also Fig. 10). Thus, for the WAO, we used the relationship recently obtained by Matsuoka et al. (2012) (i.e., DOC $(\mu \mathrm{M})=55+$ $\left.357 \cdot a_{\mathrm{CDOM}}(443)\right)$. These two regressions were used to estimate DOC concentrations from space using $a_{\mathrm{CDOM}}(443)$ derived from ocean color data. Note that DOC concentrations were estimated only for river-influenced coastal waters where tight relationships between DOC and CDOM are observed.

\subsection{Statistical analyses}

Bio-optical quantities are often log-normally distributed in natural environments (Campbell, 1995). The normality of distribution for log-transformed $a_{\mathrm{tw}}(443)$ and $a_{\mathrm{CDOM}}(443)$ values was examined for Arctic waters using a KolmogorovSmirnov test. If the normality of distribution was verified for a variable, we conducted either a $t$ test (two variables) or ANOVA (analysis of variance) to examine a difference in mean values for each pair of data. If a variable was not normally distributed, we conducted a nonparametric Wilcoxon rank-sum test. Geometric mean and geometric SD (standard deviation) were thus obtained for these variables in this study. Otherwise, arithmetic mean and SD were used. $r^{2}$ and $p$ val-
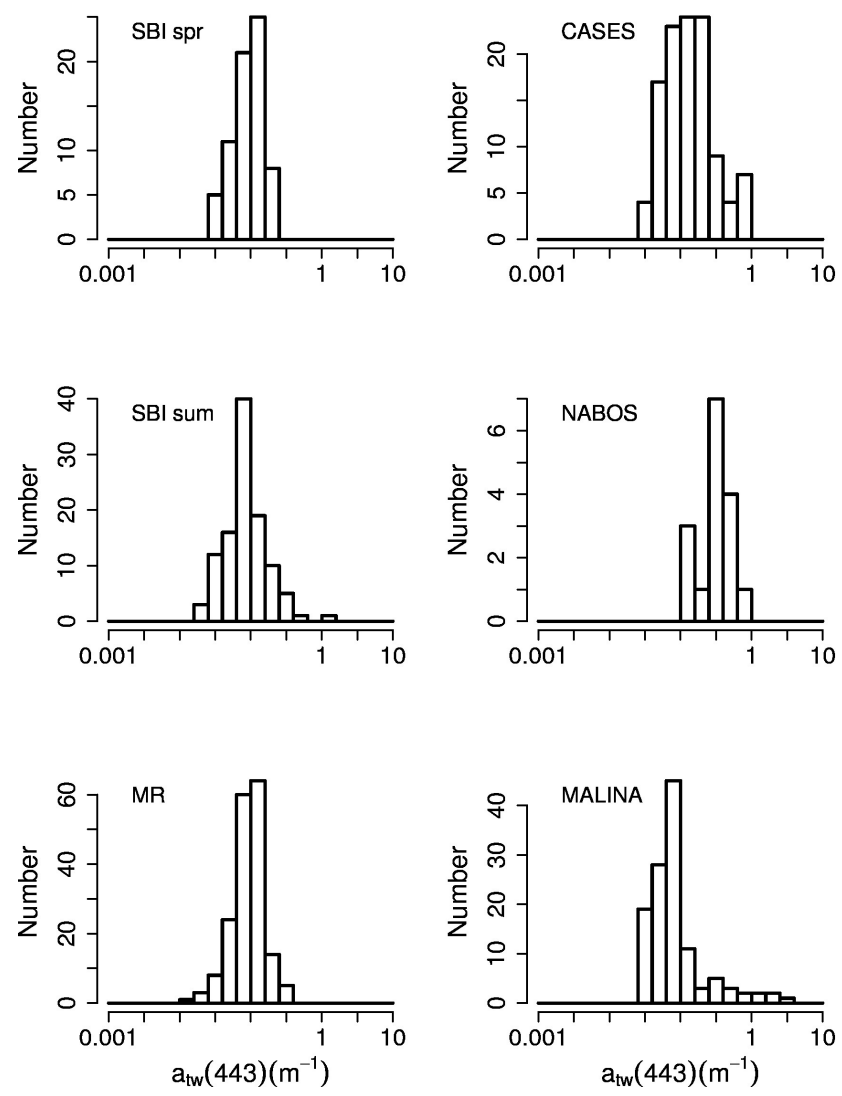

Figure 2. Histogram of the total nonwater absorption at $443 \mathrm{~nm}$ $\left(a_{\mathrm{tw}}(443), \mathrm{m}^{-1}\right)$ for SBI spr, SBI sum, MR (left) and CASES, NABOS, MALINA (right).

ues were calculated using linear regression analysis. To evaluate the performance of our CDOM algorithm, root mean square error (RMSE), mean normalized bias (MNB), and absolute percent difference (APD) were used:

RMSE $=\sqrt{\frac{\sum_{n=1}^{N}\left[\log _{10} a_{\mathrm{CDOM}}^{\mathrm{mod}}(443)-\log _{10} a_{\mathrm{CDOM}}^{\mathrm{obs}}(443)\right]^{2}}{N}}$

$\mathrm{MNB}=\frac{100}{N} \times \sum_{n=1}^{N}\left(\frac{\log _{10} a_{\mathrm{CDOM}}^{\mathrm{mod}}(443)-\log _{10} a_{\mathrm{CDOM}}^{\mathrm{obs}}(443)}{\log _{10} a_{\mathrm{CDOM}}^{\mathrm{obs}}(443)}\right)$

$\mathrm{APD}=\frac{100}{N} \times \sum_{n=1}^{N} \frac{\left|\log _{10} a_{\mathrm{CDOM}}^{\mathrm{mod}}(443)-\log _{10} a_{\mathrm{CDOM}}^{\mathrm{obs}}(443)\right|}{\log _{10} a_{\mathrm{CDOM}}^{\mathrm{obs}}(443)}$

\section{Results and discussion}

\subsection{Absorption budget}

In view of ocean color applications for the Arctic Ocean, the total nonwater absorption properties were examined first. 

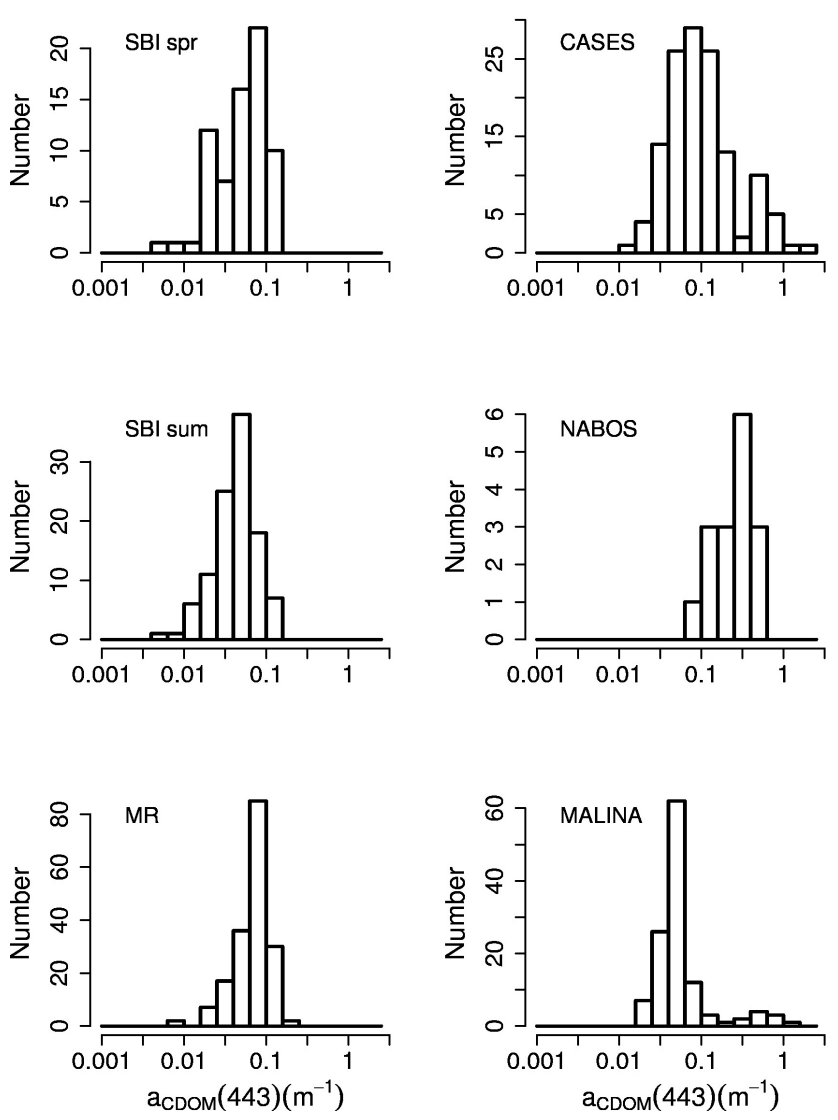

Figure 3. Histogram of CDOM absorption at $443 \mathrm{~nm}\left(a_{\mathrm{CDOM}}(443)\right.$, $\mathrm{m}^{-1}$ ) for SBI spr, SBI sum, MR (left) and CASES, NABOS, MALINA (right).

We found that $a_{\mathrm{tw}}(443)$ in river-influenced coastal waters (i.e., CASES, NABOS, and MALINA) tended to be higher than in oceanic waters (i.e., SBI spr, SBI sum, and MR) (Fig. 2). This result is consistent with the fact that river discharge largely influences absorption properties for the southern Beaufort and Siberian seas, but not for the Chukchi Sea and the western part of the Beaufort Sea (Matsuoka et al., 2011, 2012; Amon et al., 2012). Over the Siberian shelves (or EAO), $a_{\mathrm{tw}}(443)$ was significantly higher $(p<0.001)$ than in the southern Beaufort Sea (or WAO) (Fig. 2; Table 1), which was also indirectly shown by Aas et al. (2002) using spectral diffuse attenuation coefficients of downwelling irradiance $\left(K_{\mathrm{d}}(\lambda), \mathrm{m}^{-1}\right)$ (the total nonwater absorption was not directly measured in their work).

The higher $a_{\mathrm{CDOM}}(443)$ of the EAO was partly responsible for the higher $a_{\mathrm{tw}}(443)$ compared to that of the WAO (relative contribution to $a_{\mathrm{tw}}(443)$ of $85 \pm 7 \%$ and $67 \pm 19 \%$, respectively; Fig. 3). This is also consistent with the fact that the load of DOC and CDOM in the Siberian rivers (e.g., Lena, Yenisei, and $\mathrm{Ob}$ ) is significantly higher than in the Mackenzie River (Stedmon et al., 2011). CDOM absorption is strongly correlated with DOC concentrations in riverinfluenced coastal waters of the Arctic Ocean (Matsuoka et

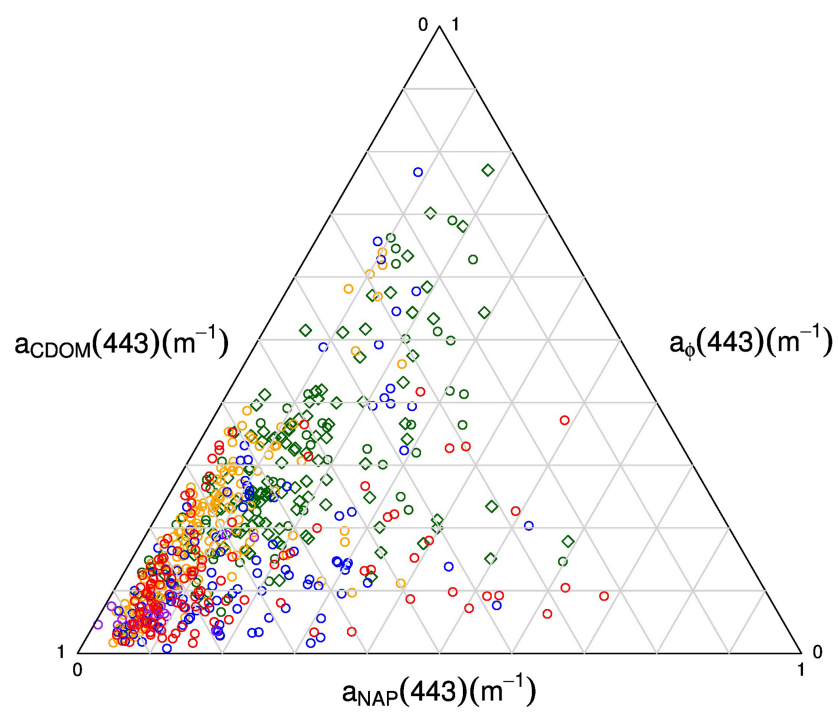

Figure 4. The contribution of absorption coefficients of phytoplankton $\left(a_{\varphi}(443), \mathrm{m}^{-1}\right)$, NAP $\left(a_{\mathrm{NAP}}(443), \mathrm{m}^{-1}\right)$, and CDOM $\left(a_{\mathrm{CDOM}}(443), \mathrm{m}^{-1}\right)$ absorption coefficients to the total nonwater absorption at $443 \mathrm{~nm}$. See Fig. 1 for symbols.

al., 2012; Walker et al., 2013). The higher CDOM absorption in the EAO likely reflects higher DOC concentrations in high-latitude watersheds of Siberia compared to those in North America (Raymond et al., 2007). This topic is further discussed in Sect. 3.4.

The strong contribution of CDOM absorption is consistent with the fact that the Arctic Ocean receives the largest amount of freshwater relative to its volume $(11 \%$ of global freshwater input while its volume is only $1 \%$ of the global ocean, Siklomanov, 1993). While this high contribution of CDOM absorption is well acknowledged especially for the WAO in both coastal and offshore waters (Bélanger et al., 2006, 2013; Matsuoka et al., 2007, 2009, 2011), it is evidenced as well here for the EAO (Fig. 4), confirming the characteristic for the whole Arctic region $(68 \pm 19 \%, N=$ 603; Table 1). Consequently, waters include a high proportion of CDOM for both oceanic and coastal waters of the Arctic Ocean, significantly influencing several estimates such as $K_{\mathrm{d}}(\lambda)$ and PP as derived from ocean color data (e.g., Arrigo and van Dijken, 2011; Reynolds et al., 2014; Arrigo et al., 2014).

\subsection{Parameterization}

While Matsuoka et al. (2011) examined absorption properties of the WAO, the majority of the data in that study were obtained for oceanic waters. To generalize the absorption properties for Arctic waters, large data sets of absorption in coastal waters from both the southern Beaufort and Siberian seas were added and analyzed in this study.

To examine differences in bio-optical properties between the WAO and EAO, $a_{\mathrm{p}}(443)$ was plotted as a function of $\operatorname{chl} a$ 

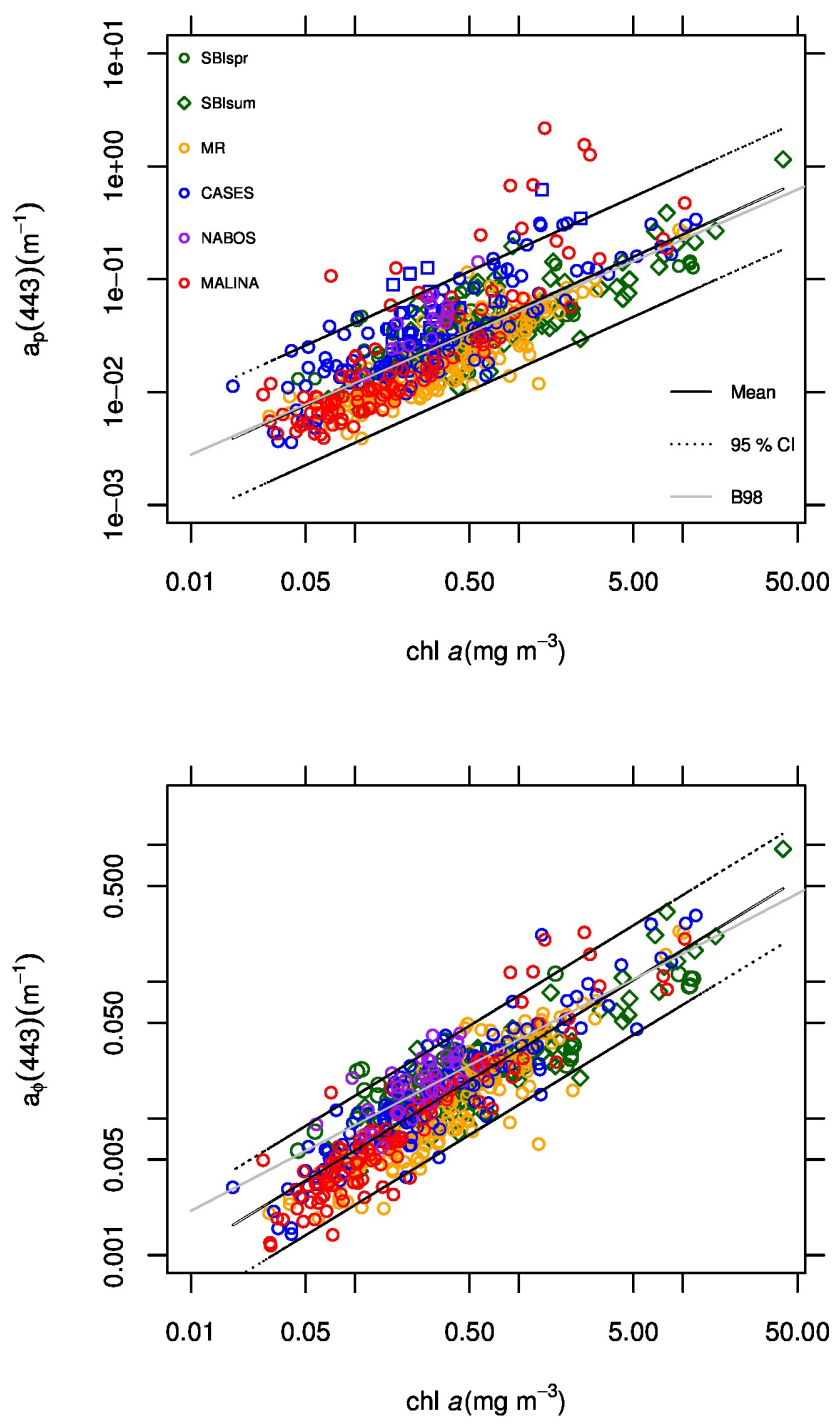

Figure 5. (a) Relationship between the total particulate absorption coefficients at $443 \mathrm{~nm}\left(a_{\mathrm{p}}(443), \mathrm{m}^{-1}\right)$ and chl $a$ for our Arctic data sets. The regression line $\left(a_{\mathrm{p}}(443)=0.0548[\mathrm{chl} a]^{0.658}, N=657\right.$; $p<0.0001)$ and $\pm 95 \%$ confidence intervals are displayed. The regression line obtained by Bricaud et al. (1998) (grey) is also overlaid for comparison. (b) Relationship between $a_{\varphi}(443)$ and chl $a$ $\left(a_{\varphi}(443)=0.0315[\mathrm{chl} a]^{0.733}, N=657 ; p<0.0001\right)$.

(Fig. 5a). Even when the outliers, observed outside the $95 \%$ confidence intervals, were included, $a_{\mathrm{p}}(443)$ showed significant positive correlation with chl $a\left(r^{2}=0.62, p<0.0001\right.$; $N=657$ ), which was quite similar to the correlation observed by Bricaud et al. (1998) at lower latitudes. A high pigment packaging effect has been acknowledged as a common feature for Arctic phytoplankton absorption, resulting in lower chl $a$-specific $a_{\varphi}(\lambda)\left(a_{\varphi}^{*}(\lambda), \mathrm{m}^{2} \mathrm{mg} \operatorname{chl} a^{-1}\right)$ values relative to those at lower latitudes (e.g., Mitchell, 1992; Matsuoka et al., 2011). Because particulate absorption is composed of phytoplankton and NAP absorption, higher NAP ab-
Table 2. Average values and standard deviations of $a_{\mathrm{NAP}}$ (443) normalized by SPM $\left(a_{\mathrm{NAP}}(443)^{*}, \mathrm{~m}^{2} \mathrm{~g}^{-1}\right)$. For comparison, values obtained for the COASTLOOC cruises in the literature (Babin et al., 2003) are also shown.

\begin{tabular}{lccc}
\hline & Cruise & $a_{\mathrm{NAP}}(443)^{*}$ & $N$ \\
\hline This study & CASES & $0.0360 \pm 0.0275$ & 107 \\
& NABOS & $0.0014 \pm 0.0019$ & 15 \\
& MALINA & $0.0602 \pm 0.0300$ & 121 \\
\hline & All & $0.0459 \pm 0.0324$ & 243 \\
& All but NABOS & $0.0488 \pm 0.0312$ & 228 \\
\hline Babin et al. (2003) & COASTLOOC & $0.0410 \pm 0.0230$ & 328 \\
\hline
\end{tabular}

Table 3. Correlations between $a_{\phi}(\lambda)$ and $a_{\phi}(443)$ in this study.

\begin{tabular}{lccccc}
\hline$a_{\phi}(\lambda)$ at wavelength & 412 & 490 & 555 & 670 & $N$ \\
\hline$r^{2}$ & 0.98 & 0.99 & 0.87 & 0.95 & 993 \\
\hline
\end{tabular}

sorption values for Arctic waters compared to those at lower latitudes ( $p<0.05$; Table 2$)$ leads to a similar $a_{\mathrm{p}}(443)$ versus chl $a$ relationship. The higher NAP likely originates from materials derived from glaciers and delivered by river runoff or from coastal erosion by ice (Mitchell and Holm-Hansen, 1991; Hodgkins et al., 2003), by accumulation of organic material in sea ice due to atmospheric deposition of aerosols or by ice algae in situ production (Bélanger et al., 2013). The SPM-specific NAP absorption at $443 \mathrm{~nm}\left(a_{\mathrm{NAP}}(443)\right.$, $\mathrm{m}^{2} \mathrm{~g}^{-1}$ ) for the WAO was significantly higher than for the EAO (Table 2). This difference likely results from geological differences between the two areas (e.g., Amon et al., 2012).

Figure $5 \mathrm{~b}$ represents the relationship between $a_{\varphi}(443)$ and chl $a$. Less variability in this relationship was observed compared to the $a_{\mathrm{p}}(443)$ versus chl $a$ relationship. A strong correlation between the two variables was found $\left(r^{2}=0.78\right.$, $p<0.0001 ; N=657)$. As expected, this regression line at chl $a<1.0 \mathrm{mg} \mathrm{m}^{-3}$ was significantly below the one obtained by Bricaud et al. (1998) at lower latitudes, demonstrating the higher pigment packaging effect for Arctic waters.

It should be stressed that while significantly higher $a_{\mathrm{CDOM}}(443)$ in the EAO was observed compared to in the WAO (Figs. 3, 4), the $a_{\varphi}(443)$ versus chl $a$ relationships between the EAO (or NABOS data set) and WAO (or the rest of the data sets) showed no significant difference or were statistically similar ( $p=0.35, F$ test). Despite the geographical difference between the WAO and EAO, this result suggests that the same relationship can be applied for both. More importantly, because our semianalytical CDOM absorption algorithm is based on chl $a$-specific $a_{\varphi}(\lambda)$ estimates (Matsuoka et al., 2013), this result highlights that our algorithm can be applied not only for the WAO but also for the EAO.

Matsuoka et al. (2011) and Wang et al. (2005) showed that $a_{\varphi}(\lambda)$ in the visible spectral domain is highly correlated 


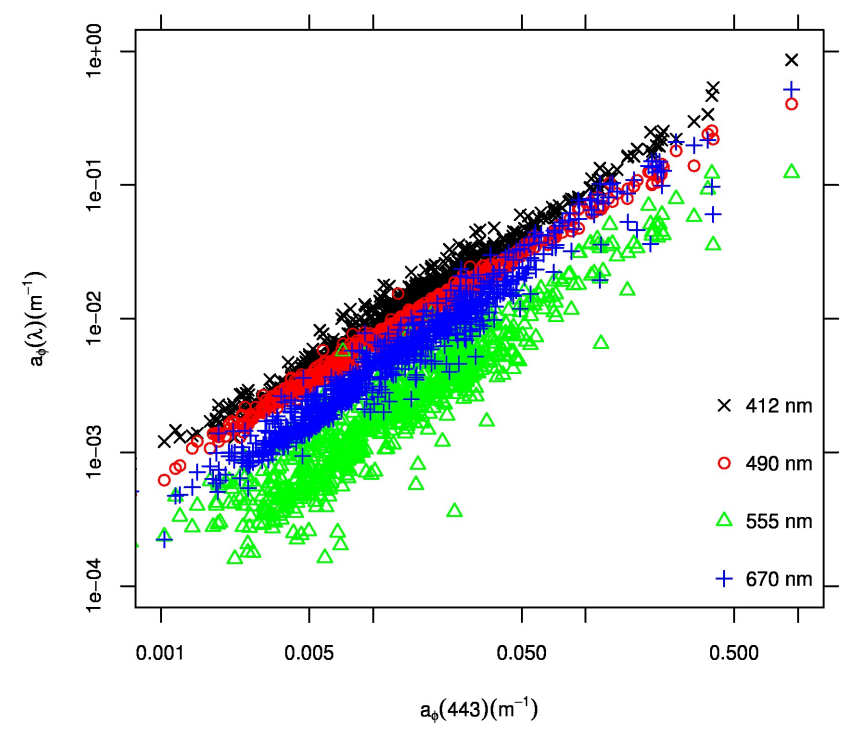

Figure 6. Relationship between $a_{\varphi}(443)$ and $a_{\varphi}(\lambda)$ at 412, 490, 555 , and $670 \mathrm{~nm}$. Coefficients of determination are shown in Table 3.

with $a_{\varphi}(443)$, which can be obtained using ocean color data. While a large data set including both oceanic and coastal waters was used in this study ( $N=993), a_{\varphi}(\lambda)$ showed excellent correlation with $a_{\varphi}(443)$ (Fig. 6, Table 3). This kind of statistical approach allows obtaining spectral $a_{\varphi}(\lambda)$ values using ocean color data, which can be further used for operating a spectral primary production model from space.

Statistics for $a_{\mathrm{CDOM}}(443)$ and $a_{\mathrm{NAP}}(443)$ and their spectral slopes are shown in Table 4. Results are consistent with those provided by Matsuoka et al. (2011), although much larger data sets obtained from various locations were used in the present study ( $N=859$, compared to $N=408$ in Matsuoka et al., 2011), suggesting the ubiquitous features in waters of the Arctic Ocean.

\subsection{Evaluation of the CDOM absorption algorithm}

Estimates of DOC concentrations in Arctic river-influenced coastal waters using ocean color data are reliable when CDOM absorption values are appropriately derived (Matsuoka et al., 2013). We evaluated the performance of a tuned semianalytical CDOM absorption algorithm using our Arctic data sets (Fig. 7); in this study, all data from MALINA, ICESCAPE1 and ICESCAPE2 data sets were used for this evaluation, whereas Matsuoka et al. (2013) only used data from the MALINA data set. It is important to recall that this evaluation was performed using independent data sets (e.g., MALINA, ICESCAPE1, and ICESCAPE2 data sets) that were not used for developing the algorithm (i.e., data from SBI spr, SBI sum, and MR cruises were used for this development). Results showed that the semianalytical CDOM algorithm works reasonably well (Table 5). On av-

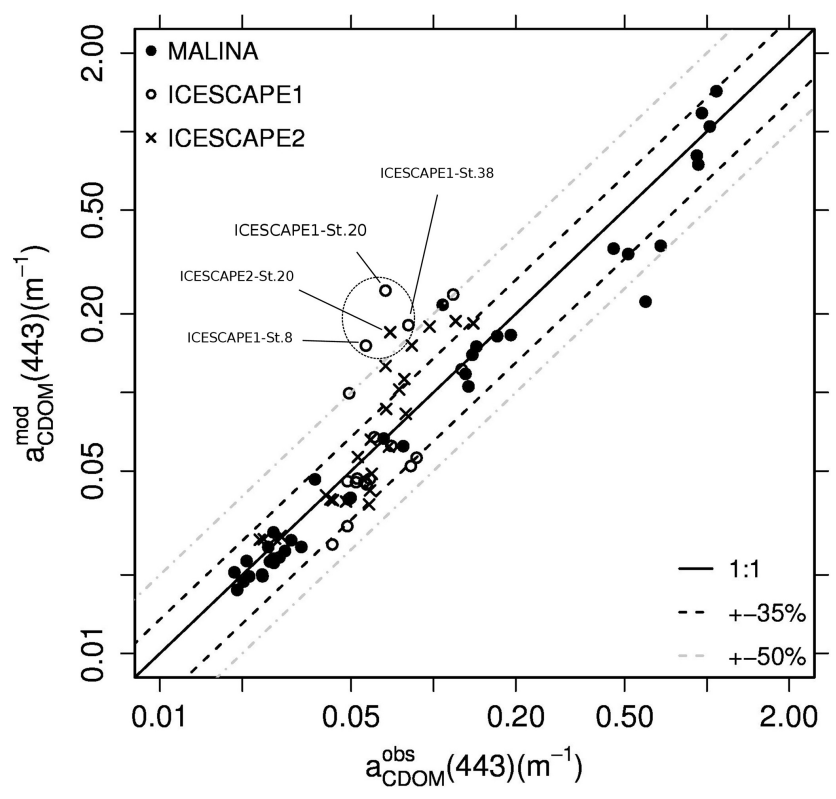

Figure 7. A comparison of estimated CDOM absorption $\left(a_{\mathrm{CDOM}}^{\mathrm{mod}}(443), \mathrm{m}^{-1}\right)$ and in situ measurements $\left(a_{\mathrm{CDOM}}^{\mathrm{obs}}(443)\right.$, $\mathrm{m}^{-1}$ ) using data sets (MALINA, ICESCAPE1, and ICESCAPE2) that were not used for developing our CDOM algorithm (i.e., data from SBI spr, SBI sum, and MR cruises were used for the algorithm's development). Phytoplankton absorption spectra for four data points above the $50 \%$ error are shown and explained in Fig. A3 and Appendix A3.

erage, $a_{\mathrm{CDOM}}(443)$ can be derived using our CDOM algorithm with a mean normalized bias (MNB) of $8.58 \%$ and absolute percent difference (APD) of $11.72 \%$. Only four data points were located above the $50 \%$ error intervals (circles in Fig. 7). A possible cause for these values could be the presence of mycosporine-like amino acids (MAAs) released by algal cells in CDOM (see Appendix A3). Although in situ $R_{\mathrm{rs}}(\lambda)$ data in the EAO are currently not available to validate the algorithm in this area, this result gives confidence that $a_{\mathrm{CDOM}}(443)$ can be derived accurately using ocean color data.

\subsection{Ocean color application}

Based on the evaluation of our CDOM algorithm as well as bio-optical properties as shown above, we derived $a_{\mathrm{CDOM}}(443)$ from satellite data $\left(a_{\mathrm{CDOM}}^{\mathrm{sat}}(443), \mathrm{m}^{-1}\right)$ by applying this algorithm to MODIS climatological data (Fig. 8). To our knowledge, this is the first synoptic view of $a_{\mathrm{CDOM}}(443)$ for the whole Arctic Ocean using a semianalytical approach. Waters with high CDOM absorption are more widely distributed in the EAO (e.g., Laptev and Kara seas) than in the WAO (e.g., southern Beaufort Sea). For August, geometric mean (G. Mean) and geometric standard deviation (G. SD) values of $a_{\mathrm{CDOM}}^{\text {sat }}(443)$ in the southern Beaufort Sea (0.059 and $2.363 \mathrm{~m}^{-1}$, respectively) were similar to our field 
Table 4. Statistics of $a_{\mathrm{CDOM}}(443)$ and $a_{\mathrm{NAP}}(443)$ at $443 \mathrm{~nm}$ with their spectral slopes, $S_{\mathrm{CDOM}}$ and $S_{\mathrm{NAP}}$, respectively.

\begin{tabular}{llllll}
\hline Cruise & $\begin{array}{l}a_{\mathrm{CDOM}}(443) \\
\text { geometric } \\
\text { mean (SD) }\end{array}$ & $\begin{array}{l}\mathrm{S}_{\mathrm{CDOM}} \\
\text { arithmetic mean } \\
\pm 1 \mathrm{SD}\end{array}$ & $\begin{array}{l}a_{\mathrm{NAP}}(443) \\
\text { geometric } \\
\text { mean (SD) }\end{array}$ & $\begin{array}{l}\text { S } \\
\text { arithmetic mean } \\
\pm 1 \mathrm{SD}\end{array}$ & $N$ \\
\hline SBI spr & $0.0534(2.1231)$ & $0.0184 \pm 0.0036$ & $0.0114(2.4180)$ & $0.0095 \pm 0.0022$ & 80 \\
SBI sum & $0.0429(1.7890)$ & $0.0205 \pm 0.0035$ & $0.0115(2.7128)$ & $0.0102 \pm 0.0015$ & 111 \\
MR & $0.0662(1.6732)$ & $0.0155 \pm 0.0031$ & $0.0062(2.1135)$ & $0.0108 \pm 0.0009$ & 179 \\
CASES & $0.0992(2.6003)$ & $0.0198 \pm 0.0027$ & $0.0187(4.3476)$ & $0.0103 \pm 0.0011$ & $132(173)$ \\
NABOS & $0.2463(1.8366)$ & $0.0209 \pm 0.0044$ & $0.0141(2.7972)$ & $0.0165 \pm 0.0062$ & $31(22)$ \\
MALINA & $0.0559(2.1947)$ & $0.0185 \pm 0.0013$ & $0.0078(4.8963)$ & $0.0070 \pm 0.0014$ & $326(436)$ \\
\hline All & $0.0642(2.2577)$ & $0.0184 \pm 0.0032$ & $0.0095(3.9657)$ & $0.0090 \pm 0.0026$ & $859(1001)$ \\
\hline
\end{tabular}
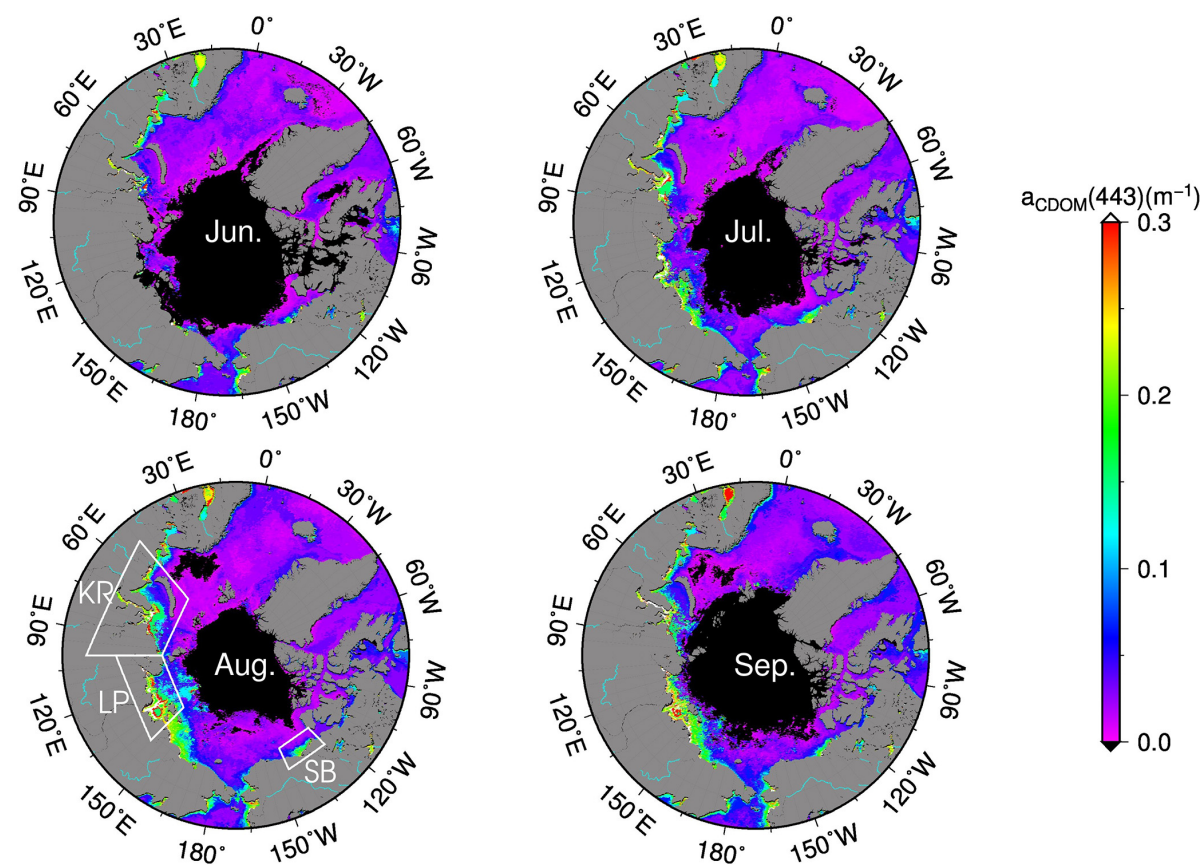

Figure 8. Climatology of CDOM absorption at $443 \mathrm{~nm}$ from satellite sensors $\left(a_{\mathrm{CDOM}}^{\mathrm{sat}}(443), \mathrm{m}^{-1}\right)$ from June to September, obtained by applying our CDOM absorption algorithm to MODIS monthly-averaged climatology of $R_{\mathrm{rs}}(\lambda)$ data over the 2002-2012 period. Three areas were defined for examination of $a_{\mathrm{CDOM}}^{\text {sat }}(443)$ values as follows: southern Beaufort (SB: $\left.125-145^{\circ} \mathrm{W}, 68-72^{\circ} \mathrm{N}\right), \mathrm{Laptev}\left(\mathrm{LP}: 100-145^{\circ} \mathrm{E}\right.$, $69-77^{\circ} \mathrm{N}$ ), and Kara seas (KR: $\left.50-100^{\circ} \mathrm{E}, 64-77^{\circ} \mathrm{N}\right)$. Histograms of $a_{\mathrm{CDOM}}^{\mathrm{sat}}(443)$ values within these areas are shown in Fig. 9.

Table 5. Comparison of $a_{\mathrm{CDOM}}(443)$ estimates $\left(a_{\mathrm{CDOM}}^{\mathrm{mod}}(443)\right.$, $\left.\mathrm{m}^{-1}\right)$ with in situ $a_{\mathrm{CDOM}}(443)\left(a_{\mathrm{CDOM}}^{\mathrm{obs}}(443), \mathrm{m}^{-1}\right)$ using independent data sets that were not used for developing the CDOM algorithm. Data from MALINA, ICESCAPE1, and ICESCAPE2 were used. RMSE, MNB, APD, $r^{2}$, intercept, and slope are provided.

\begin{tabular}{lccccccc}
\hline Data sets & $r^{2}$ & Intercept & Slope & RMSE & MNB & APD & $N$ \\
\hline This study & 0.87 & -0.022 & 0.97 & 0.069 & 8.58 & 11.72 & 79 \\
\hline
\end{tabular}

observations for the MALINA cruise $\left(0.055\right.$ and $2.265 \mathrm{~m}^{-1}$, respectively) during the same time period (Matsuoka et al., 2012). G. Mean and G. SD values for $a_{\mathrm{CDOM}}^{\text {sat }}(443)$ in the
Laptev (0.138 and $2.833 \mathrm{~m}^{-1}$, respectively) and Kara seas $\left(0.073\right.$ and $3.037 \mathrm{~m}^{-1}$, respectively) are higher than those in the southern Beaufort Sea (Fig. 9). The highest $a_{\mathrm{CDOM}}^{\text {sat }}(443)$ value observed in the Kara Sea $\left(4.353 \mathrm{~m}^{-1}\right)$ is consistent with in situ measurements (up to $5 \mathrm{~m}^{-1}$; Stedmon et al., 2011; Heim et al., 2013; Orek et al., 2013). In addition to our evaluation shown in Fig. 7, this result highlights the reliability of satellite ocean color data for Arctic waters (see also Fig. 5 in Matsuoka et al., 2013).

To estimate DOC concentrations in river-influenced coastal waters using ocean color data, a DOC concentration versus CDOM absorption relationship needs to be established. Matsuoka et al. (2012) recently showed a strong 

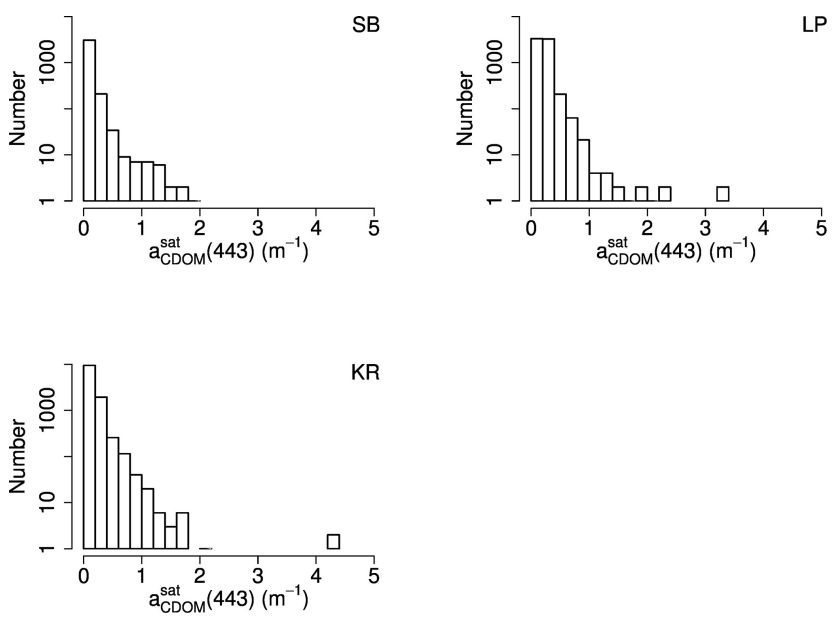

Figure 9. Histogram of $a_{\mathrm{CDOM}}^{\text {sat }}{ }^{(443)}$ values in the SB, the LP, and the KR seas defined in Fig. 8.

correlation between the two variables in southern Beaufort Sea waters $\left(r^{2}=0.97 ; p<0.0001\right)$. Similarly, DOC concentrations were well correlated with $a_{\mathrm{CDOM}}(443)$ in the EAO (Walker et al., 2013). It is important to note that the DOC versus $a_{\mathrm{CDOM}}(443)$ relationships differ between the WAO and EAO (Fig. 10), suggesting that different relationships between DOC and $a_{\mathrm{CDOM}}(443)$ need to be applied for the EAO and WAO. Different DOC versus salinity relationships between the WAO and EAO were also reported (Hansell et al., 2004). There are likely differences in vegetation between watersheds that influence the relative amounts of colored and noncolored dissolved organic matter.

To estimate DOC concentrations in the near surface waters of the Arctic Ocean, the regression of DOC versus $a_{\mathrm{CDOM}}(443)$ shown in Fig. 10 was applied to the $a_{\mathrm{CDOM}}^{\text {sat }}(443)$ image. Similarly to $a_{\mathrm{CDOM}}^{\text {sat }}(443)$ distribution, waters showing high DOC concentrations were widely distributed in the EAO compared to WAO (Fig. 11). The G. Means of DOC concentrations estimated from satellite data $\left(\mathrm{DOC}^{\mathrm{sat}}, \mu \mathrm{M}\right)$ in the southern Beaufort Sea $(82 \mu \mathrm{M})$ were of the same order of magnitude as in situ measurements for the MALINA cruise (79 $\mu$ M: Matsuoka et al., 2012). The values in the Laptev $(279 \mu \mathrm{M})$ and Kara seas $(267 \mu \mathrm{M})$ were higher than in the southern Beaufort Sea (Fig. 12), which is consistent with in situ measurements (Amon et al., 2012; Walker et al., 2013). The high DOC concentrations in the EAO are likely due to higher DOC concentrations in the high-latitude watersheds of Siberia compared to those in North America (Raymond et al., 2007; Stedmon et al., 2011).

As an example of application of our DOC algorithm, spatial variability in DOC estimates from 2009 to 2011 was examined (Fig. 13). While the Mackenzie River plume stayed near coast on 4 August 2010, the plume extended far offshore toward north approximately two weeks later. This plume diminished on 7 September 2010. In 2011, river plume tended

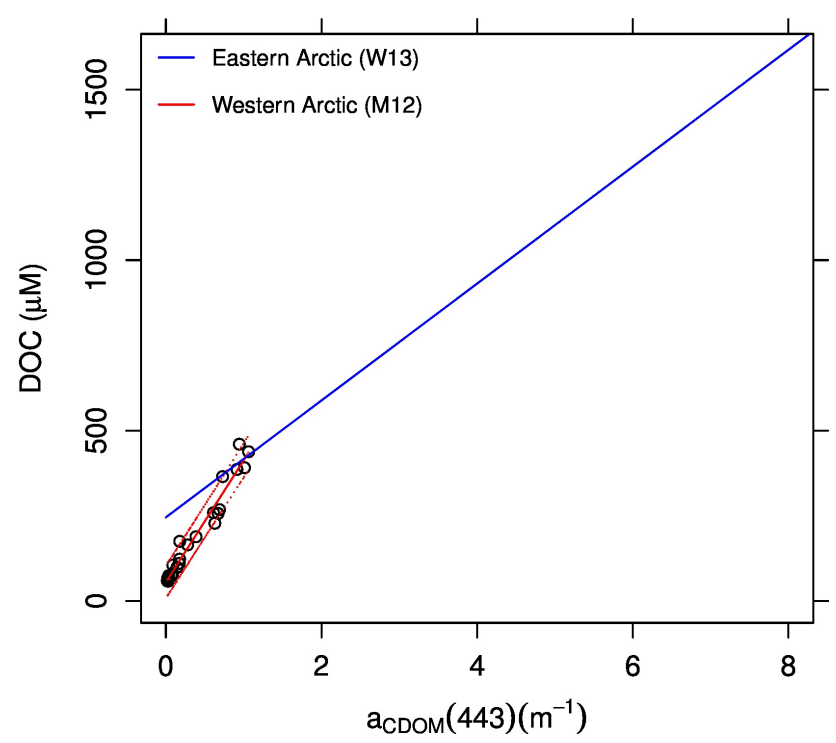

Figure 10. In situ relationships between DOC and $a_{\mathrm{CDOM}}(443)$ for the WAO (M12: Matsuoka et al., 2012; $r^{2}=0.97, p<$ $\left.0.0001 ; \mathrm{DOC}=55+357 \cdot a_{\mathrm{CDOM}}(443)\right)$ and EAO (W13: Walker et al., 2013; $r^{2}=0.90, p<0.0001 ;$ DOC $=245+$ $\left.171 \cdot a_{\mathrm{CDOM}}(443)\right)$. Data points and $95 \%$ confidence intervals for M12 are shown as black circles and red dotted lines, respectively. The ranges of $a_{\mathrm{CDOM}}(443)$ and DOC concentrations for the regressions provided by M12 and W13 and applied in this study were as follows: $0.018 \mathrm{~m}^{-1}<a_{\mathrm{CDOM}}(443)<1.08 \mathrm{~m}^{-1}$; $55 \mu \mathrm{M}<\mathrm{DOC}<500 \mu \mathrm{M} ; 0.39 \mathrm{~m}^{-1}<a_{\mathrm{CDOM}}(443)<8.4 \mathrm{~m}^{-1}$; and $166 \mu \mathrm{M}<\mathrm{DOC}<1660 \mu \mathrm{M}$.

to distribute North West direction from 29 July to 2 August 2011. The plume then diminished by 12 September 2011 . Note that patterns of the Mackenzie River plume distribution are mainly controlled by wind direction (e.g., Carmack et al., 1989). Thus, spatial and temporal variability in DOC estimates were clearly observed using our algorithm.

Ongoing global warming will likely increase the release of presently sequestered carbon that originates, in part, from thawing of the permafrost (e.g., Frey and Smith, 2005; Stedmon et al., 2011). Continuous monitoring and quantification of DOC concentrations and the budget for the whole Arctic Ocean are therefore urgently required to better understand modifications in carbon cycling as a result of global warming.

\section{Conclusions}

This study examined light absorption properties of the Arctic Ocean using a large data set including both oceanic and coastal waters. Our results clearly showed the specificity of those properties: high proportion of CDOM absorption, and high pigment packaging effect. Despite the high proportion of CDOM absorption to the total nonwater absorption, the relationship between phytoplankton absorption at $443 \mathrm{~nm}$ and 

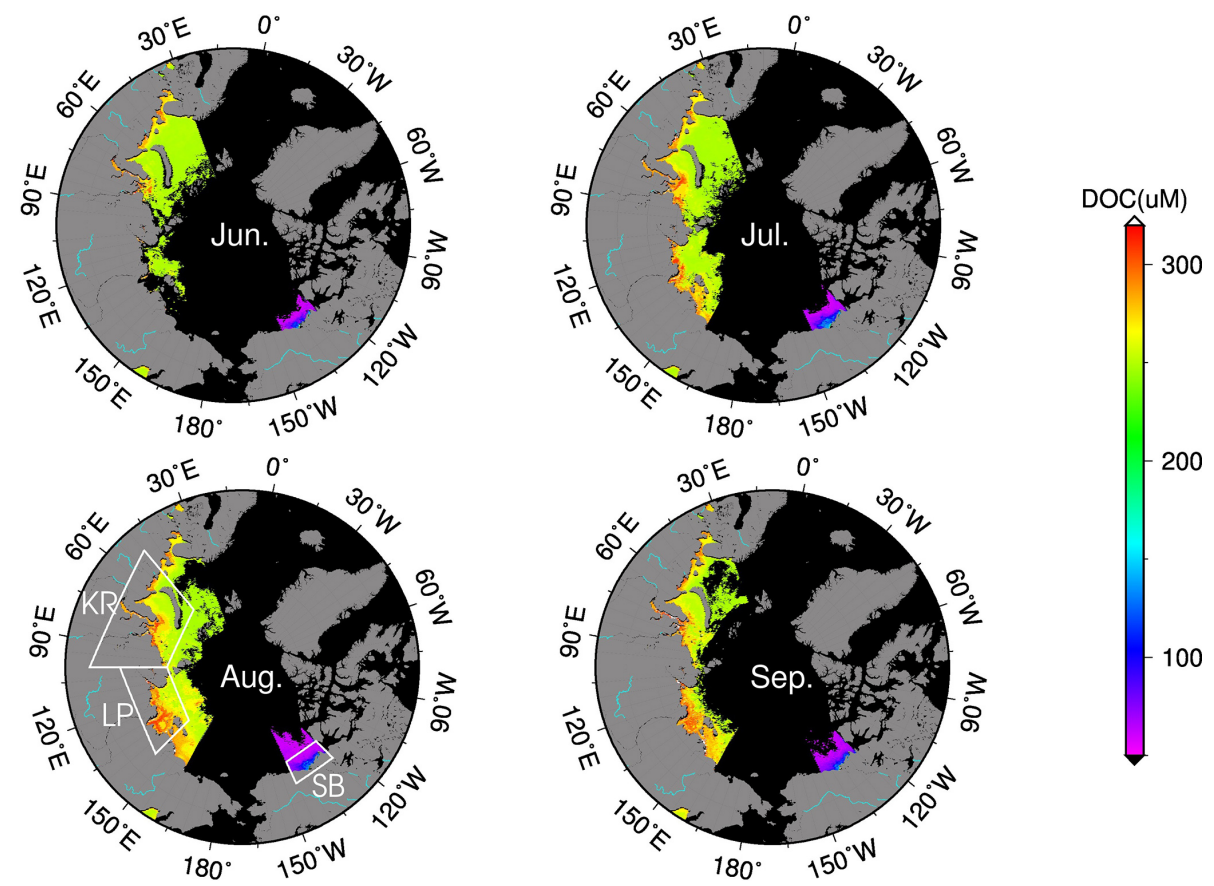

200

100

Figure 11. Climatology of DOC concentrations in Arctic river-influenced coastal waters (DOC ${ }^{\text {sat }}$ ) from June to September, obtained by applying the DOC versus $a_{\mathrm{CDOM}}(443)$ regressions to the $a_{\mathrm{CDOM}}^{\text {sat }}(443)$ images shown in Fig. 8. For the WAO, the regression obtained by Matsuoka et al. (2012) was applied within the measured range of $a_{\mathrm{CDOM}}(443)$ (i.e., $0.018<a_{\mathrm{CDOM}}(443)<1.08 \mathrm{~m}^{-1}$ ). For the EAO, the regression obtained by Walker et al. (2013) was applied within the measured range of $a_{\mathrm{CDOM}}(443)$ (i.e., $a_{\mathrm{CDOM}}(443)<8.4 \mathrm{~m}^{-1}$ ). To obtain those values, $a_{\mathrm{CDOM}}(443)$ was estimated from $a_{\mathrm{CDOM}}(350)$ by assuming $S_{\mathrm{CDOM}}=0.0175 \mathrm{~nm}^{-1}$ for the EAO (Aas et al., 2002 ; Stedmon et al., 2011). Histograms of DOC ${ }^{\text {sat }}$ values within the white boxes defined in Fig. 8 are shown in Fig. 12.
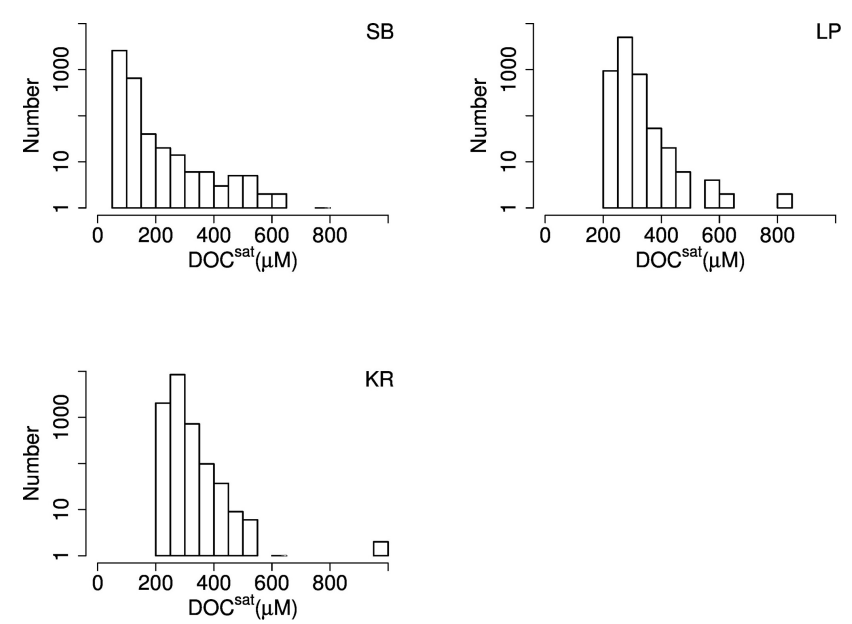

Figure 12. Histogram of DOC ${ }^{\text {sat }}$ values in the SB, LP, and KR seas defined in Fig. 8.

chl $a$ concentration was not significantly different between the WAO and EAO. Our semianalytical CDOM algorithm depends on chl $a$-specific $a_{\varphi}(\lambda)$ estimates, highlighting the applicability for the whole Arctic Ocean. Using DOC versus $a_{\mathrm{CDOM}}(443)$ relationships, DOC concentrations in riverinfluenced coastal waters can now be estimated semianalyt- ically using satellite ocean color data. Our statistical results demonstrated that both $a_{\mathrm{CDOM}}(443)$ values and DOC concentrations obtained using satellite ocean color data are reasonable compared to in situ measurements, suggesting its potential utility for obtaining a quantitative estimate of the carbon budget of the Arctic Ocean.

The DOC budget of the Arctic Ocean is expected to change rapidly due to sea ice reduction, permafrost thawing, and river discharge increases as consequences of global warming. To examine this issue temporally and geographically using satellite ocean color data, we developed a semianalytical algorithm for estimating DOC concentrations in Arctic river-influenced coastal waters. Compared to empirical algorithms that have been proposed (e.g., Mannino et al., 2008; Fichot and Benner, 2011), because CDOM absorption is semianalytically derived from ocean color data, this algorithm depends less on empirical relationships established for particular time periods and areas. Another semianalytical algorithm using difference equations for inherent optical properties (IOPs) was also developed in the Kara Sea (Korosov et al., 2012). Our pan-Arctic data set and robust semianalytical methods should improve satellite estimates of DOC concentrations in surface waters of the Arctic Ocean and help to enhance our understanding of modifications of DOC cycles 

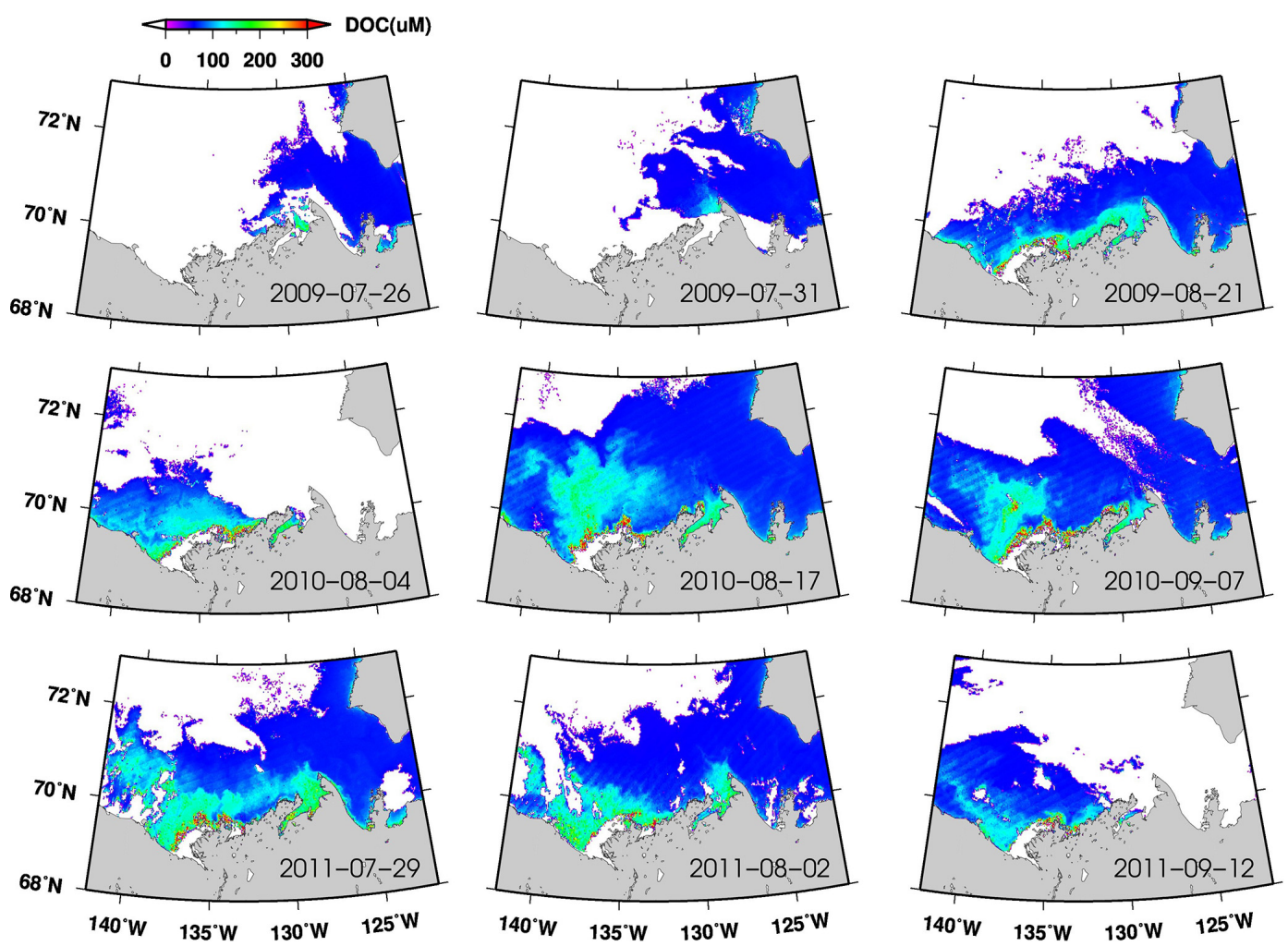

Figure 13. Satellite-derived DOC concentrations in the surface layer for selected MODIS Aqua satellite data recorded in 2009 (top), 2010 (middle), and 2011 (bottom).

in the Arctic Ocean. Further work regarding interannual variability in DOC budget is required.

We acknowledge that an issue regarding the seasonal variability in the relationship between DOC concentrations and CDOM absorption needs to be considered. While no study examining this issue has yet been conducted so far for Arctic waters, Mannino et al. (2008) demonstrated in the U.S. middle-Atlantic Bight that the intercept of the DOC versus $a_{\mathrm{CDOM}}(443)$ relationship changed seasonally in their study region, whereas the slope remained unchanged. This result suggests that seasonal relationships should be established to improve the estimates of DOC concentrations from space.

Acknowledgements. We are grateful to the captain and crews of the Canadian icebreaker CCGS Amundsen, USCGC Healy, Japanese R/V Mirai, and R/V Viktor Buynitsky. Data sets from SBI2002 cruises were provided by V. Hill on the basis of the applicable data policy (http://www.eol.ucar.edu/projects/sbi/). Sampling for these cruises was supported by the Arctic System Sciences program of the National Science Foundation OPP-0125049 and 0223375 and the National Aeronautics and Space Administration (NASA) Sensor Intercomparison and Merger for Biological and Interdisciplinary Studies (SIMBIOS) program NAG510528. Sampling for the ICESCAPE cruises was supported by NASA grant NNX10AF42G to Kevin Arrigo. ICESCAPE data used here were supported by NASA as follows: PRR 800 radiome- ter (NNX11AF64G to B. G. Mitchell) and particle absorption (NNX10AG05G to R. Reynolds and D. Stramski). Absorption data for ICESCAPE cruises were provided by R. Reynolds and D. Stramski.

This study was conducted as part of the MALINA Scientific Program funded by ANR (Agence Nationale de la Recherche), INSU-CNRS (Institut National des Sciences de l'Univers - Centre National de la Recherche Scientifique), CNES (Centre National d'Études Spatiales) and the ESA (European Space Agency). We also thank a joint contribution to the research programs of UMI Takuvik, ArcticNet (Network Centres of Excellence of Canada) and the Canada Excellence Research Chair in Remote Sensing of Canada's New Arctic Frontier.

Comments by E. Boss, A. Mannino, and an anonymous reviewer have greatly helped in improving the manuscript.

Edited by: E. Boss

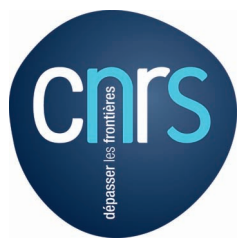

The publication of this article is financed by CNRS-INSU. 


\section{Appendix A:}

\section{A1 Comparison of chl $a$ determination by the HPLC and fluorometric methods}

Chl $a$ concentrations determined fluorometrically (chl $a^{\text {fluo }}$ ) were compared to those using the HPLC ( $\mathrm{chl} a^{\mathrm{HPLC}}$ ) technique (Fig. A1). Correlation between the two quantities was high $\left(r^{2}=0.89, N=177\right)$, and slope was not significantly different from the $1: 1$ line $(p<0.0001)$. This result suggests that in this study, chl $a^{\text {fluo }}$ can appropriately replace chl $a^{\mathrm{HPLC}}$ when chl $a^{\mathrm{HPLC}}$ is not available.

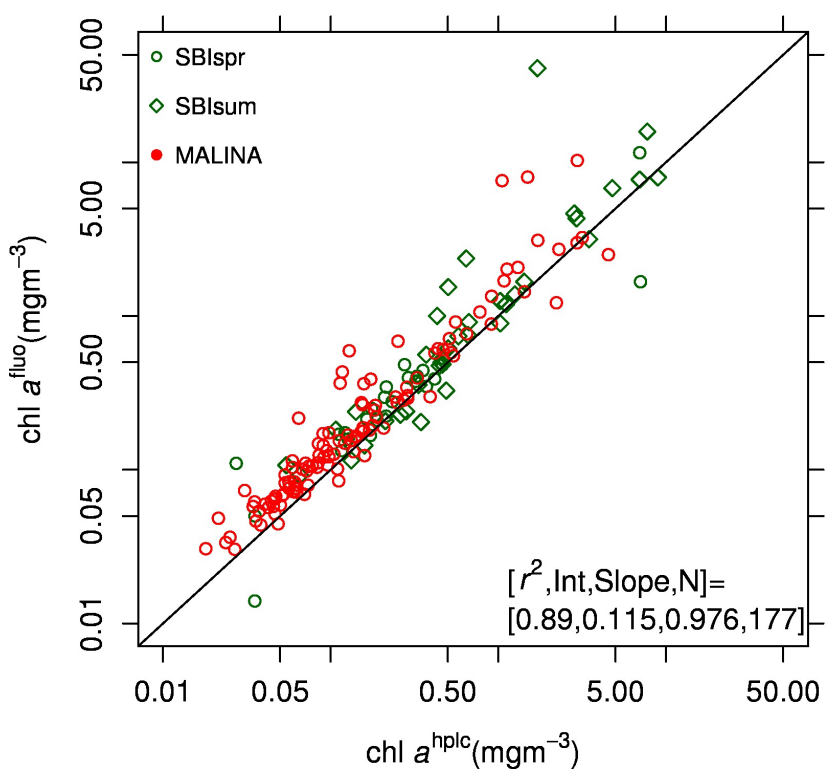

Figure A1. Comparison of chl $a$ determined fluorometrically (chl $a^{\text {fluo }}$ ) and chl $a$ using the HPLC method (chl $\left.a^{\text {HPLC }}\right)$.

\section{A2 Evaluation of estimated phytoplankton absorption using the Bricaud and Stramski (1990) method}

We evaluated the performance of the Bricaud and Stramski (1990) method to estimate phytoplankton absorption using total particulate absorption data from the ICESCAPE1 cruise (Fig. A2). Results showed that $a_{\varphi}(\lambda)$ values can be derived with high accuracy using this method at wavelengths in the visible spectral domain. This method was used for the NABOS data set.

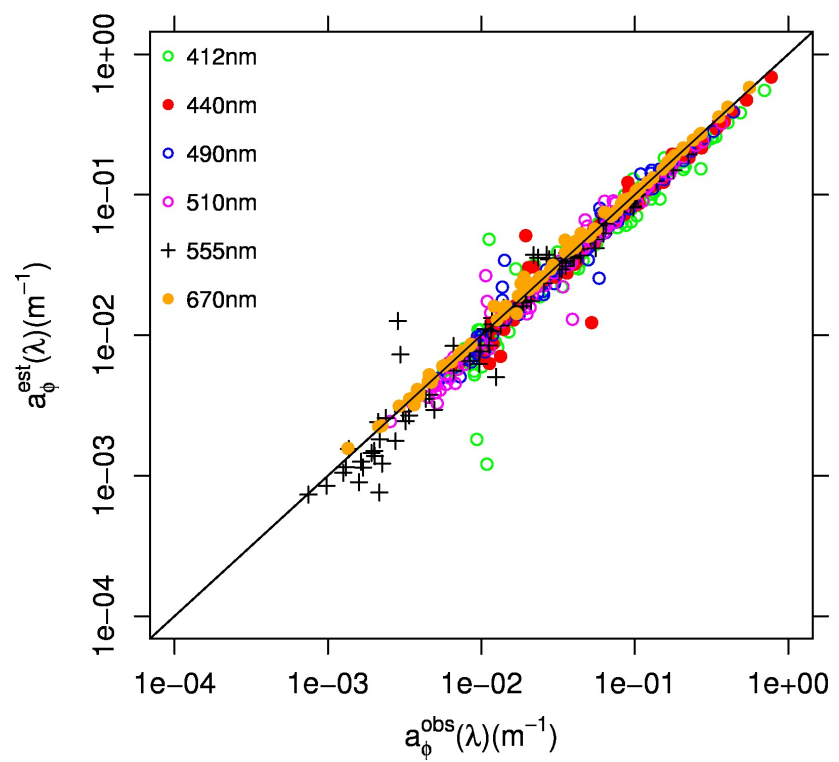

Figure A2. Comparison of $a_{\varphi}(\lambda)$ estimated using the Bricaud and Stramski (1990) method with in situ measurements during the ICESCAPE1 cruise.

\section{A3 High UV absorption for some phytoplankton communities}

High values in phytoplankton absorption spectra around $330 \mathrm{~nm}$ were observed at four stations during ICESCAPE cruises. The presence of mycosporine-like amino acids (MAAs) in natural waters has been reported at all latitudes (e.g., Karsten et al., 1991, 1998; Whitehead and Vernet, 2000; Tilstone et al., 2010). Most of the MAAs' absorption peaks are observed at 330-334 $\mathrm{nm}$ due to several types of MAAs (e.g., shinorine, porphyra-334, asterina; Carreto et al., 2005; Llewellyn and Airs, 2010). A clear bump was also observed at $360 \mathrm{~nm}$ at station 38 during ICESCAPE1, which corresponded to the peak of palythene (Llewellyn and Airs, 2010). Although actual concentrations of MAAs during our observations are not available, the strong UV (ultraviolet) absorption observed for some samples in this study suggest MAAs were present. Since MAAs are water soluble, they may be released from the cells upon freezingmelting processes of sea ice, senescence, or grazing entering the dissolved organic pool and hence contribute to our $a_{\mathrm{CDOM}}(443)$ estimates (circles in Fig. 7). It is interesting to note that $a_{\varphi}(\lambda)$ at 330 and $360 \mathrm{~nm}$ can influence $R_{\mathrm{rS}}(\lambda)$ in the visible spectral domain. A similar result was also observed using an empirical relationship between $a_{\mathrm{CDOM}}(443)$ and $K_{\mathrm{d}}(380) / K_{\mathrm{d}}(780)$ (Hooker, unpublished). The strong impact of MAAs' absorption and spectral reflectance in the UV spectral domain during a massive red tide was reported by Kahru and Mitchell (1998) and is the basis for the red tide index published for the global imager (GLI) algorithm (Mitchell and Kahru, 2009). This influence of MAAs on 
UV-visible absorption may allow estimates of MAAs using ocean color data in the future if the challenge of atmospheric correction in the UV spectral domain can be solved.

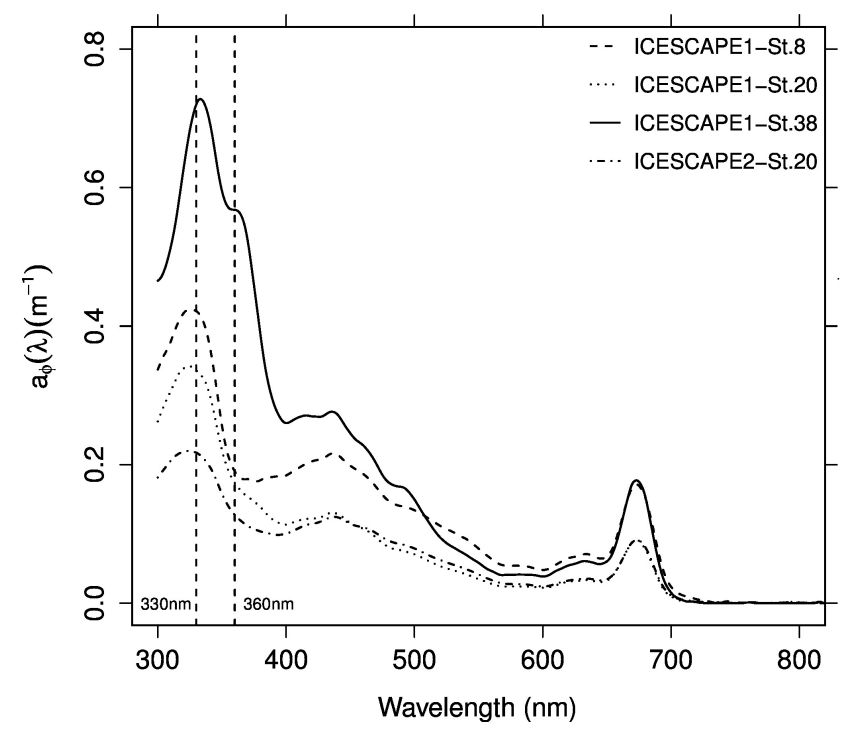

Figure A3. Spectra of phytoplankton absorption coefficients $\left(a_{\varphi}(\lambda), \mathrm{m}^{-1}\right)$ at four stations during ICESCAPE1 and 2 cruises. CDOM absorption estimates at these points were outside of the $50 \%$ errors as shown in Fig. 7. 


\section{References}

Aas, E., Hokedai, J., Hojersley, N. K., Sandvik, R., and Sakshaug, E.: Spectral properties and UV-attenuation in Arctic Marine waters, in: UV Radiation and Arctic Ecosystems, edited by: Hessen, D. O., Springer, Berlin, 23-56, 2002.

Allali, K., Bricaud, A., and Claustre, H.: Spatial variations in the chlorophyll-specific absorption coefficients of phytoplankton and photosynthetically active pigments in the Equatorial Pacific, J. Geophys. Res., 102, 12413-12423, 1997.

Amon, R. M. W., Rinehart, A. J., Duan, S., Louchouarn, P., Prokushkin, A., Guggenberger, G., Bauch, D., Stedmon, C., Raymond, P. A., Holmes, R. M., McClelland, J. W., Peterson, B. J., Walker, S. A., and Zhulidov, A. V.: Dissolved organic matter sources in large Arctic rivers, Geochim. Cosmochim. Ac., 94, 217-237, 2012.

Ardyna, M., Babin, M., Gosselin, M., Devred, E., Bélanger, S., Matsuoka, A., and Tremblay, J.-É.: Parameterization of vertical chlorophyll $a$ in the Arctic Ocean: impact of the subsurface chlorophyll maximum on regional, seasonal, and annual primary production estimates, Biogeosciences, 10, 4383-4404, doi:10.5194/bg-10-4383-2013, 2013.

Arrigo, K. R. and van Dijken, G. L.: Secular trends in Arctic Ocean net primary production, J. Geophys. Res., 116, C09011, doi:10.1029/2011JC007151, 2011.

Arrigo, K. R., Hill, V., Bélanger, S., Hirawake, T., and Mitchell, G. B.: Estimates of net primary production from spacebased measurements, in: IOCCG Report on Polar Seas, submitted, 2014.

Babin, M., Stramski, D., Ferrari, G. M., Claustre, H., Bricaud, A., Obolensky, G., and Hoepffner, N.: Variations in the light absorption coefficients of phytoplankton, nonalgal particles, and dissolved organic matter in coastal waters around Europe, J. Geophys. Res., 108, 3211, doi:10.1029/2001JC00082, 2003.

Bélanger, S., Xie, H., Krotkov, N., Larouche, P., Vincent, W. F., and Babin, M.: Photomineralization of terrigenous dissolved organic matter in Arctic coastal waters from 1979 to 2003: interannual variability and implications of climate change, Global Geochem. Cycles, 20, GB4005, doi:10.1029/2006GB002708, 2006.

Bélanger, S., Cizmeli, S. A., Ehn, J., Matsuoka, A., Doxaran, D., Hooker, S., and Babin, M.: Light absorption and partitioning in Arctic Ocean surface waters: impact of multiyear ice melting, Biogeosciences, 10, 6433-6452, doi:10.5194/bg-10-6433-2013, 2013.

Benner, R., Louchouarn, P., and Amon, R. M. W.: Terrigenous dissolved organic matter in the Arctic Ocean and its transport to surface and deep waters of the North Atlantic, Global Biogeochem. Cy., 19, GB2025, doi:10.1029/2004GB002398, 2005.

Ben Mustapha, S., Bélanger, S., and Larouche, P.: Evaluation of ocean color algorithms in the Southern Beaufort Sea, Canadian Arctic: new parameterization using SeaWiFS, MODIS, and MERIS spectral bands, Can. J. Remote Sens., 38, 1-22, 2012.

Bricaud, A. and Stramski, D.: Spectral absorption coefficients of living phytoplankton and nonalgal biogenous matter: a comparison between the Peru upwelling area and the Sargasso Sea, Limnol. Oceanogr., 35, 562-582, 1990.

Bricaud, A., Morel, A., Babin, M., Allali, K., and Claustre, H.: Variations of light absorption by suspended particles with chlorophyll $a$ concentration in oceanic (Case 1) waters: analysis and implications for bio-optical models, J. Geophys. Res., 103, 31033-31044, 1998.

Campbell, J. W.: The lognormal distribution as a model for biooptical variability in the sea, J. Gephys. Res., 100, 13237-13254, 1995.

Carmack, E. C., Macdonald, R. W., and Papadakis, J. E.: Water mass structure and boundaries in the Mackenzie shelf esturary, J. Geophys. Res., 94, 18043-18055, 1989.

Carreto, J. I., Carignan, M. O., and Montoya, N. G.: A highresolution reverse-phase liquid chromatography method for the analysis of mycosporine-like amino acids (MAAs) in marine organisms, Mar. Biol., 146, 237-252, doi:10.1007/s00227-0041447-y, 2005.

Cleveland, J. S. and Weidemann, A. D.: Quantifying absorption by aquatic particles: a multiple scattering correction for glass-fiber filters, Limnol. Oceanogr., 38, 1321-1327, 1993.

Comiso, J. C., Parkinson, C. L., Gersten, R., and Stock, L.: Accelerated decline in the Arctic sea ice cover, Geophys. Res. Lett., 35, L01703, doi:10.1029/2007GL031972, 2008.

Doxaran, D., Ehn, J., Bélanger, S., Matsuoka, A., Hooker, S., and Babin, M.: Optical characterisation of suspended particles in the Mackenzie River plume (Canadian Arctic Ocean) and implications for ocean colour remote sensing, Biogeosciences, 9, 3213 3229, doi:10.5194/bg-9-3213-2012, 2012.

Fichot, C. G. and Benner, R.: A novel method to estimate DOC cocentrations from CDOM absorption coefficients in coastal waters, Geophys. Res. Lett., 38, L03610, doi:10.1029/2010GL046152, 2011.

Frey, K. E. and Smith, L. C.: Amplified carbon release from vast West Siberian peatlands by 2100 , Geophys. Res. Lett., 32, L09401, doi:;10.1029/2004GL022025, 2005.

Garver, S. A. and Siegel, D. A.: Inherent optical property inversion of ocean color spectra and its biogeochemical interpretation, time series from the Sargasso Sea, J. Geophys. Res., 102, 1860718625, 1997.

Hansell, D. A., Kadko, D., and Bates, N. R.: Degradation of terrigenous dissolved organic carbon in the western Arctic Ocean, Science, 304, 858-861, 2004.

Heim, B., Abramova, E., Doerffer, R., Günther, F., Hölemann, J., Kraberg, A., Lantuit, H., Loginova, A., Martynov, F., Overduin, P. P., and Wegner, C.: Ocean Colour remote sensing in the Southern Laptev Sea: evaluation and applications, Biogeosciences Discuss., 10, 3849-3889, doi:10.5194/bgd-10-38492013, 2013.

Hodgkins, R., Cooper, R., Wadham, J., and Tranter, M.: Suspended sediment fluxes in a high-Arctic glacierised catchment: implications for fluvial sediment storage, Sediment. Geol., 162, 105117, 2003.

Holm-Hansen, O., Lorenzen, C. J., Holms, R. W., and Strickland, J. D. H.: Fluorometric determination of chlorophyll, J. Cons. Perm. Int. Explor. Mer., 30, 3-15, 1965.

Hooker, S. B., Morrow, J. H., and Matsuoka, A.: Apparent optical properties of the Canadian Beaufort Sea - Part 2: The $1 \%$ and $1 \mathrm{~cm}$ perspective in deriving and validating AOP data products, Biogeosciences, 10, 4511-4527, doi:10.5194/bg-10-4511-2013, 2013.

IOCCG: Remote sensing of ocean colour in coastal, and opticallycomplex, waters, in: Reports of the International Ocean-Colour 
Coordinating Group, no. 3, edited by: Sathyendranath, S., Dartmouth, 140 pp., 2000.

Kahru, M. and Mitchell, B. G.: Spectral reflectance and absorption of a massive red tide off Southern California, J. Geophys. Res., 103, 21601-21609, 1998.

Karentz, D., McEuen, F. S., Land, M. C., and Dunlap, W. C.: Survey of mycosporine-like amino acids in Antarctic marine organisms: potential protection from ultraviolet exposure, Mar. Biol., 108, 157-166, 1991.

Karsten, U., Sawall, T., Hanelt, D., Bischof, K., Figueroa, F. L., Flores-Moya, A., and Wiencke, C.: An inventory of UVabsorbing mycosporine-like amino acids in macroalgae from polar to warm-temperate regions, Bot. Mar., 41, 443-453, 1998.

Kishino, M., Takahashi, M., Okami, N., and Ishimaru, S.: Estimation of the spectral absorption coefficients of phytoplankton the sea, B.. Mar. Sci., 37, 634-642, 1985.

Korosov, A. A., Pozdnyakov, D. V., and Grassl, H.: Spaceborne quantitative assessment of dissolved organic carbon fluxes in the Kara Sea, Advances Space Res., 50, 1173-1188, 2012.

Kwok, R.: Near zero replenishment of the Arctic multiyear sea ice cover at the end of 2005 summer, Geophys. Res. Lett., 34, L05501, doi:10.1029/2006GL028737, 2007.

Llewellyn, C. A. and Airs, R. L.: Distribution an abundance of MAAs in 33 species of microalgae across 13 classes, Mar. Drugs, 8, 1273-1291, doi:10.3390/md8041273, 2010.

Mannino, A., Russ, M. E., and Hooker, S. B.: Algorithm development and validation for satellite-derived distributions of DOC and CDOM in the US Middle Atlantic Bight, J. Geophys. Res., 113, C07051, doi:10.1029/2007JC004493, 2008.

Maritorena, S., Siegel, D. A., and Peterson, A. R.: Optimization of a semianalytical ocean color model for global-scale applications, Appl. Optics, 41, 2705-2714, 2002.

Matsuoka, A., Huot, Y., Shimada, K., Saitoh, S., and Babin, M.: Bio-optical characteristics of the Western Arctic Ocean: implications for ocean color algorithms, Can. J. Remote Sens., 33, 503-518, 2007.

Matsuoka, A., Larouche, P., Poulin, M., Vincent, W., and Hattori, H.: Phytoplankton community adaptation to changing light levels in the southern Beaufort Sea, Canadian Arctic, Estuar. Coast. Shelf S., 82, 537-546, 2009.

Matsuoka, A., Hill, V., Huot, Y., Bricaud, A., and Babin, M.: Seasonal variability in the light absorption properties of western Arctic waters: parameterization of the individual components of absorption for ocean color applications, J. Geophys. Res., 116, C02007, doi:10.1029/2009JC005594, 2011.

Matsuoka, A., Bricaud, A., Benner, R., Para, J., Sempéré, R., Prieur, L., Bélanger, S., and Babin, M.: Tracing the transport of colored dissolved organic matter in water masses of the Southern Beaufort Sea: relationship with hydrographic characteristics, Biogeosciences, 9, 925-940, doi:10.5194/bg-9-925-2012, 2012.

Matsuoka, A., Hooker, S. B., Bricaud, A., Gentili, B., and Babin, M.: Estimating absorption coefficients of colored dissolved organic matter (CDOM) using a semi-analytical algorithm for southern Beaufort Sea waters: application to deriving concentrations of dissolved organic carbon from space, Biogeosciences, 10, 917-927, doi:10.5194/bg-10-917-2013, 2013.

Mitchell, B. G. and Kiefer, D. A.: Chlorophyll $a$ specific absorption and fluorescence excitation spectra for light-limited phytoplankton, Deep-Sea Res. Pt. I, 35, 639-663, 1988.
Mitchell, B. G. and Holm-Hansen, O.: Bio-optical properties of Antarctic Peninsula waters: differentiation from temperate ocean models, Deep-Sea Res., 38, 1009-1028, 1991.

Mitchell, B. G.: Predictive bio-optical relationships for polar oceans and marginal ice zones, J. Marine Syst., 3, 91-105, 1992.

Mitchell, B. G., Kahru, M., Wieland, J., and Stramska, M.: Determination of spectral absorption coefficients of particles, dissolved materials and phytoplankton for discrete water samples, in: Ocean Optics Protocols For Satellite Ocean Color Sensor Validation, Revision 4, Volume 4: Inherent Optical Properties: Instruments, Characterization, Field Measurements and Data Analysis Protocols, NASA Tech. Rep., Greenbelt, Maryland, 39-64, 2003.

Mitchell, B. G. and Kahru, M.: Bio-optical algorithms for ADEOS2 GLI, J. Remote Sens. Soc. Japan , 29, 80-85, 2009.

Morrow, J. H., Hooker, S. B., Booth, C. R., Bernhard, G., Lind, R. N., and Brown, J. W.: Advances in measuring the Apparent Optical Properties (AOPs) of optically complex waters, NASA Tech. Memo. 2010-215856, NASA Goddard Space Flight Center, Greenbelt, Maryland, 42-50, 2010.

Mueller, J. L. and Austin, R. W.: Ocean Optics Protocols for SeaWiFS Validation, Revision 1, NASA Tech. Memo. 104566, Vol. 25, edited by: Hooker, S. B., Firestone, E. R., and Acker, J. G., NASA GSFC, Greenbelt, Maryland, 67 pp., 1995.

Örek, H., Doerffer, R., Röttgers, R., Boersma, M., and Wiltshire, K. H.: A bio-optical model for remote sensing of Lena water, Biogeosciences Discuss., 10, 4887-4925, doi:10.5194/bgd10-4887-2013, 2013.

Osburn, C., Retamal, L., and Vincent, W. F.: Photoreactivity of chromophoric dissolved organic matter transported by the Mackenzie River to the Beaufort Sea, Mar. Chem., 115, 10-20, 2009.

Pegau, S., Zaneveld, J. R., and Mueller, J. L.: Beam transmission and attenuation coefficients: instruments, characterization, field measurements, and data analysis, in: Ocean Optics Protocols for Satellite Ocean Color Sensor Validation, Revision 4, NASA Tech. Memo. Volume 4, edited by: Mueller, J. L., Giulietta, S., Fargion, S., McClain, C. R., NASA GSFC, Greenbelt, Maryland, 76 pp., 2003.

Raymond, P. A., McClelland, J. W., Holmes, R. M., Zhulidov, A. V., Mull, K., Peterson, B. J., Striegl, R. G., Aiken, G. R., and Gurtovaya, T. Y.: Flux and age of dissolved organic carbon exported to the Arctic Ocean: a carbon isotopic study of the five largest arctic rivers, Global Biogeochem. Cy., 21, GB4011, doi:10.1029/2007GB002934, 2007.

Reynolds, R., Matsuoka, A., Hirawake, T., and Mitchell, G.: Ocean color algorithms and bio-optical relationships for polar seas, IOCCG on polar seas, submitted, 2014.

Rottgers, R. and Gehnke, S.: Measurement of light absorption by aquatic particles: improvement of the quantitative filter technique by use of an integrating sphere approach, Appl. Optics, 51, 13361351, 2012.

Shiklomanov, I. A.: World fresh water resources, in: Water in Crisis: a Guide to the World's Fresh Water Resources, edited by: Gleick, P. H., Oxford Univ. Press, New York, 13-24, 1993.

Stroeve, J., Serreze, M., Drobot, S., Gearheard, S., Holland, M., Maslanik, J., Meier, W., and Scambos, T.: Arctic sea ice extent plummets in 2007, EOS Trans. AGU, 89, 13-14, 2008. 
Tassan, S. and Ferrari, G. M.: An alternative approach to absorption measurements of aquatic particles retained on filters, Limnol. Oceanogr., 40, 1358-1368, 1995.

Tassan, S. and Ferrari, G. M.: A sensitivity analysis of the "Transmitance-Reflectance" method for measuring high absorption by aquatic particles, J. Phyto. Res., 24, 757-774, 2002.

Terrado, R., Lovejoy, C., Massana, R., and Vincent, W. F.: Microbial food web responces to light and nutrients beneath the coastal Arctic Ocean sea ice during the winter-spring transition, J. Marine Syst., 74, 964-977, 2008.

Tilstone, G. H., Airs, R. L., Martinez-Vicente, V., Widdicombe, C., and Llewellyn, C.: High concentrations of mycosporine-like amino acids and colored dissolved organic matter in the sea surface microlayer off the Iberian Peninsula, Limnol. Oceanogr., 55, 1835-1850, 2010.

Twardowski, M. S., Boss, E., Sullivan, J. M., and Donaghay, P. L.: Modeling the spectral shape of absorption by chromophoric dissolved organic matter, Mar. Chem., 89, 69-88, 2004.

Stedmon, C. A., Amon, R. M. W., Rinehart, A. J., and Walker, S. A.: The supply and characteristics of colored dissolved organic matter (CDOM) in the Arctic Ocean: pan Arctic trends and differences, Mar. Chem., 124, 108-118, 2011.
Suzuki, R. and Ishimaru, T.: An improved method for the determination of phytoplankton chlorophyll using $\mathrm{N}, \mathrm{N}$ dimethylformamide, J. Oceanogr., 46, 190-194, 1990.

Walker, S., A., Amon, R. M. W., and Stedmon, C. A.: Variations in high-latitude riverine fluorescent dissolved organic matter: A comparison of large Arctic rivers, J. Geophys. Res., 118, 1-14, doi:10.1002/2013/JG002320, 2013.

Wang, J., Cota, G., and Ruble, D. A.: Absorption and backscattering in the Beaufort and Chukchi Seas, J. Geophys. Res., 110, C04014, doi:10.1029/2002JC001653, 2005.

Wheeler, P. A., Gosselin, M., Sherr, E., Thibault, D., Kirchman, D. L., Benner, R., and Whiteledge, T. E.: Active cycling of organic carbon in the Central Arctic Ocean, Nature, 380, $697-$ 699, 1996.

Whitehead, K. and Vernet, M.: Influence of mycosporine-like amino acids (MAAs) on UV absorption by particulate and dissolved organic matter in La Jolla Bay, Limnol. Oceanogr., 45, 1788-1796, 2000. 